NBER WORKING PAPER SERIES

\title{
OPTIMAL EXCHANGE RATE POLICY: \\ THE INFLUENCE OF PRICE SETTING AND ASSET MARKETS
}

\author{
Charles Engel \\ Working Paper 7889 \\ http://www.nber.org/papers/w7889 \\ NATIONAL BUREAU OF ECONOMIC RESEARCH \\ 1050 Massachusetts Avenue \\ Cambridge, MA 02138 \\ September 2000
}

This paper was originally prepared for the conference on "Optimal Monetary Institutions for Mexico," at ITAM, Mexico City, December 3-4, 1999. The current version is a revision of a version that was presented at the conference on "Global Monetary Integration" at the Federal Reserve Bank of Cleveland, May 31 June 2, 2000. I would like to thank the sponsors of the two conferences. Also thanks to Elisabeth Huybens, Marco del Negro, Enrique Mendoza, Marco Espinosa, Barry Eichengreen, and the referee for helpful comments, and Mick Devereux with whom I have collaborated on closely related work. Support for this paper was provided in part from a National Science Foundation grant to the National Bureau of Economic Research. The views expressed herein are those of the author and not necessarily those of the National Bureau of Economic Research.

(C) 2000 by Charles Engel. All rights reserved. Short sections of text, not to exceed two paragraphs, may be quoted without explicit permission provided that full credit, including $\mathbb{C}$ notice, is given to the source. 
Optimal Exchange Rate Policy:

The Influence of Price Setting and Asset Markets

Charles Engel

NBER Working Paper No. 7889

September 2000

JEL No. F3, F4

\section{$\underline{\text { ABSTRACT }}$}

This paper examines optimal exchange-rate policy in two-country sticky-price general equilibrium models in which households and firms optimize over an infinite horizon in an environment of uncertainty. The models are in the vein of the "new open-economy macroeconomics" as exemplified by Obstfeld and Rogoff $(1995,1998,2000)$. The conditions under which fixed or floating exchange rates yield higher welfare depend on the exact nature of price stickiness and on the degree of risksharing opportunities. This paper presents some preliminary empirical evidence on the behavior of consumer prices in Mexico that suggests failures of the law of one price are important. The evidence on price setting and risk-sharing opportunities is not refined enough to make definitive conclusions about the optimal exchange-rate regime for that country.
Charles Engel
Department of Economics
University of Wisconsin
1180 Observatory Drive
Madison, WI 53706-1393
and NBER
cengel@ssc.wisc.edu 
What is the optimal exchange rate policy for Mexico? Is replacing pesos with U.S. dollars or adopting a currency board that permanently fixes the peso to the U.S. dollar? Should the peso have a fully flexible exchange rate with the dollar? Or should Mexican monetary policy be used to target the peso/dollar exchange rate, allowing for neither fully fixed nor fully flexible rates?

The traditional approach to fixed versus floating exchange rate questions examines the short run stabilizing properties of each regime. Friedman's (1953) famous argument for floating exchange rates stipulates that in the long run the exchange rate system does not have significant real consequences. His reasoning is that the exchange rate system is ultimately a choice of monetary regimes. In the end, monetary policy does not matter for real quantities, he argues, but in the short run it does. He comments:

If internal prices were as inflexible as exchange rates, it would make little economic difference whether adjustments were brought about by changes in exchange rates or by equivalent changes in internal prices. But this condition is clearly not fulfilled. The exchange rate is potentially flexible in the absence of administrative action to freeze it. At least in the modern world, internal prices are highly inflexible.

Friedman, of course, makes the case for flexible exchange rates as a vehicle for achieving rapid changes in international relative prices.

Buiter (1999) also contends that the choice of exchange-rate regime is also pertinent only to short-run stabilization questions:

The theory of optimal currency areas is one of the low points of post-World War II monetary economics. Its key failure is a chronic confusion between transitory nominal rigidities and permanent real rigidities. The result is a greatly overblown account of the power of monetary policy to affect real economic performance, for good or for bad.

While Buiter may be overstating the irrelevance of monetary regimes for longer-run economic performance, examination of the short-run effects of monetary regimes is certainly more squarely in the tradition of modern macroeconomic thinking. 
Friedman wrote at a time in which there was little capital mobility among even the richest countries. Floating exchange rates maintained a zero current account balance, thus shutting off any channel for transmission of foreign shocks. In a series of papers, Mundell $(1960,1961,1963)$ demonstrated that the insulation properties of floating exchange rates are diminished in the presence of capital mobility. The answer to the question of which is better - fixed or floating exchange rates became more complicated, depending on whether the source of shocks was monetary or real; the degree of capital and other factor mobility; and the relative size of countries.

This paper builds two-country (the U.S. and Mexico) economic models in which agents are forward looking and optimize in an environment of uncertainty, but in which there are short-run nominal price rigidities. The models are extensions of the New Open-Economy Macroeconomic models of Obstfeld and Rogoff $(1998,2000)$. Those models, which fully incorporate uncertainty into the dynamic open-economy sticky-price general equilibrium literature, build on many precursors including, most directly, Corsetti and Pesenti (1997) and Obstfeld and Rogoff (1995). These models are examples of recent international models with optimizing agents and prices that are sticky but in which the law of one price holds for traded goods. Other examples include Rankin (1998), and Hau (2000).

While most of the aforementioned papers assume that the law of one price holds for all traded goods, the models in this paper make other pricing assumptions, building directly on the papers of Devereux and Engel (1998) and Devereux, Engel and Tille (1999). They are also related to the work of Bacchetta and van Wincoop (1998), Betts and Devereux (1996, 2000), and Chari, Kehoe and McGrattan (2000).

Most studies of Latin American economies ignore the empirical evidence of failures of the law of one price, even for traded goods. Section 1 of this paper provides some broad statistical evidence that suggests strongly that there are significant deviations from the law of one price for Mexican 
consumer goods. Indeed, it appears that these deviations are much more important in accounting for real exchange rate movements in the 1990s than changes in the relative price of traded to nontraded goods. Many studies -- including some of those at this conference, such as Cooley and Quadrini (2000), Mendoza (2000), and Schmitt-Grohé and Uríbe (2000) - assume that the law of one price holds for traded goods.

In the models presented in section 2, there are a large number of monopolistic firms in each of Mexico and the U.S. Each firm must set nominal prices for its goods one period in advance. Following Obstfeld and Rogoff (1998), firms set prices optimally to maximize the value of the firm. However, there are three types of ways in which prices can be sticky: firms can set prices in their own currencies; they can set prices in consumers' currencies; or, some firms could set prices in producers' currencies while others set them in consumers' currencies. The standard models in which prices are set in producers' currencies assume that the law of one price holds: the price of the good is fixed in the country where the goods is produced, but the price varies one-for-one with the nominal exchange rate for foreign consumers. The evidence of section 1 shows that this is a bad assumption for Mexico. Two possible alternatives are to assume that producers set prices in consumers' currencies, or that all U.S. produced goods are priced in U.S. dollars while Mexican firms set prices in consumers' currencies. The former assumption implies that consumer prices are not responsive to changes in nominal exchange rates in the short run. The law of one price fails for all goods when there are unanticipated nominal exchange rate shocks. The latter assumption means that the law of one price holds for U.S. produced goods. As the peso depreciates, the peso cost of U.S. goods increases. This is consistent with the widespread belief that Mexican producers benefit compared to foreign producers when the peso depreciates. But under this assumption, the law of one price fails for Mexican-produced goods, which could possibly account for the empirical evidence presented in section 1. 
There simply has not been sufficient study of goods pricing in Mexico (and other Latin American countries). While there has been a lot of focus on how the relative price of traded to nontraded goods change within countries, very little work has been done to investigate nominal rigidities and the law of one price. But, we shall see that the choice of exchange-rate policy depends critically on how nominal prices react in the short run to exchange-rate changes.

Another important issue in determining optimal exchange rate policy is the degree to which individuals can insure against exchange-rate changes under more flexible regimes. One notable shortcoming of the old fixed but adjustable currency peg in Mexico was the risk of occasional large devaluations. That risk may also exist under the current regime of controlled floating exchange rates. The problem is that there are not enough hedging instruments to allow agents to insure fully against these abrupt changes in exchange rates. In a world of perfectly flexible prices, a nominal devaluation would not necessarily imply any real changes in wealth. But in the short run with sticky nominal prices, nominal devaluations are inevitably real devaluations.

The new open-economy macroeconomics literature has not addressed these issues. In some models (Corsetti and Pesenti (1997), Obstfeld and Rogoff (1998)), the law of one price holds for all goods. Devaluations do not impose any purchasing power risk. Indeed, in the set-up of Obstfeld and Rogoff (1998), because exchange-rate changes immediately cause changes in prices consumers pay, terms of trade fluctuations insure against all real shocks. Just as in the flexible-price model of Cole and Obstfeld (1991), there is no need for formal insurance markets since terms of trade changes effectively completely insure. In practice, however, the law of one price fails in the short run. Nominal exchange rate fluctuations are associated with real exchange rate changes for consumers. However, the model of Devereux and Engel (1998) assumes complete (nominally-denominated) contingent claims. It cannot address the concerns of missing financial markets. 
Calvo, Leiderman, and Reinhart (1996) and Bacchetta and van Wincoop (2000), for example, document the increasing capital flows to Asian and Latin American markets in the 1980s and 1990s. But as Calvo $(1999,2000)$ has emphasized, the form of the capital flows does not provide anything like the insurance of complete markets. Liabilities of Mexico and other emerging markets are heavily denominated in dollars, and hence borrowers are subject to extreme exchange-rate risk. Eichengreen and Mody (2000) argue that much of the capital flows have been driven by investor sentiment rather than by an efficient allocation of risk. Furthermore, Ghosh and Wolf (2000) find that the surge in capital flows to LDCs is selective. Countries that are geographically isolated and have not attained a threshold level of development have received very little outside investment.

This paper takes a first step (within the "new open-economy macroeconomics" framework) toward addressing the traditional concerns of macroeconomic stability in fixed versus floating exchange rate regimes, but in a model with limited insurance markets. The model takes into account how fixed exchange rate regimes eliminate the need for insurance against nominal exchange rate shocks that lead to deviations from the law of one price. The policy conclusions are compared with the recommendations reached under the assumption of a complete market in nominal contingent claims.

Finally, a standard approach to calibrating some general equilibrium models is to take linear approximations around the long-run steady state. In the context of the models of this paper, that amounts to assuming that policy-makers care only about the variance of consumption. But, we shall see that exchange-rate policy can affect the expected level of consumption and leisure as well. ${ }^{1}$ The policy recommendations are very different if policy-makers seek only to minimize the second moment of consumption. Perhaps this suggests that we are not yet at the stage where we can expect to give accurate policy recommendations based solely on miniature general equilibrium models. A more

\footnotetext{
${ }^{1}$ In the models of this paper, leisure enters utility linearly, so the variance of leisure does not matter.
} 
fruitful avenue would be to use macroeconomic theory as a guide to some of the issues that arise in the choice of optimal monetary institutions for Mexico, while recognizing that accurate answers await better empirical evidence and more sophisticated modeling.

\section{Empirical Evidence of Local-Currency Pricing}

This section follows Engel (1999) in producing measures of the importance of deviations of the law of one price in overall variation of the real exchange rate between Mexico and the United States. The evidence is not direct evidence on nominal price stickiness, but is suggestive of the role of localcurrency pricing. Taken in conjunction with Rogers and Smith (2000), the evidence is strongly consistent with the hypothesis that at least some prices are set in the short-run in consumers' currencies and real exchange rate variation is due to fluctuating nominal exchange rates on top of sticky nominal prices.

Write the log of consumer prices in Mexico as a weighted average of traded goods and nontraded goods prices:

$$
p_{t}=\left(1-b_{t}\right) p_{t}^{T}+b_{t} p_{t}^{N}
$$

where $p_{t}$ equals the log of the consumer price level, $p_{t}^{T}$ is the log of traded goods prices, $p_{t}^{N}$ is the $\log$ of nontraded goods prices, and $b_{t}$ is the weight on nontraded goods.

Similarly in the U.S.:

$$
p_{t}=\left(1-b_{t}^{*}\right) p_{t}^{* T}+b_{t}^{*} p_{t}^{* N}
$$

where starred $(*)$ variables represent U.S. values.

Define the real exchange rate as the relative price of Mexican goods:

$$
q_{t} \equiv s_{t}+p_{t}^{*}-p_{t}
$$


From equations (1.1)-(1.3), the real exchange rate can be written as:

$$
q_{t}=x_{t}+y_{t},
$$

where

$$
\begin{gathered}
x_{t} \equiv s_{t}+p_{t}^{* T}-p_{t}^{T} \\
y_{t}=b_{t}^{*}\left(p_{t}^{* N}-p_{t}^{* T}\right)-b_{t}\left(p_{t}^{N}-p_{t}^{T}\right) .
\end{gathered}
$$

In the model of this paper, all goods are traded. Changes in the real exchange rate come only from movements in $x_{t}-$ i.e., from deviations from the law of one price. The alternative possibility is that $y_{t}$ accounts for much of the short-run variation in real exchange rates. That is the channel implicit in almost all theoretical models of real exchange rate behavior for Latin America, but that channel is missing from the model of this paper. Is it reasonable to exclude short-run changes in $y_{t}$ in describing short-run real exchange rate behavior?

The statistic $\varphi_{j}$ measures the fraction of the variance of $j$-month real exchange rate changes that is attributable to the variance of $x_{t}$ :

$$
\boldsymbol{\varphi}_{j}=\frac{\operatorname{Var}\left(x_{t+j}-x_{t}\right)}{\operatorname{Var}\left(q_{t+j}-q_{t}\right)} .
$$

There are other possible ways to decompose the variance of the real exchange rate into a part attributable to $x_{t}$ and a part attributable to $y_{t}$, depending on how the covariance of the two components is treated. This measure tends to understate the importance of the $x_{t}$ as long as the covariance term is positive (which it is at most short horizons), but any alternative treatment of the covariance has very little effect on the measured relative importance of the $x_{t}$ component. 
Engel (1999) decomposes the mean-squared error of real exchange rate movements rather than the variance. (The difference is that the mean-squared error includes the squared mean change.) In practice, that also makes little difference in the calculated share of movement assigned to $x_{t}$. Only the variance decomposition is reported here, for convenience.

If the law of one price holds, $\varphi_{j}$ should be zero at all horizons. Although one would not expect the $x_{t}$ to be zero literally in all horizons in the data, one expects $\varphi_{j}$ to be small if the relative price of nontraded goods is the chief mover of the real exchange rate.

Monthly data on consumer prices in Mexico from September 1991 - August 1999 are obtained from Datastream. For the U.S., the consumer price of "commodities" is used as the price of traded goods. (Consumer prices in the U.S. are split into commodities and services.) The exchange rate is the monthly average market rate. Measures of the overall consumer price indexes are also taken from Datastream.

Figure 1 plots $\varphi_{j}$ for $j=1,2, \ldots 24$. Given that there are only eight years of monthly data, one must treat the estimated longer variances with some skepticism.

The striking thing about Figure 1 is that at all horizons, $\varphi_{j}$ is quite large. At the 1-month horizon it is greater than 0.99. Even at the six-month horizon, it exceeds 0.96 . The smallest value reported is just slightly below 0.89 . The values of $\varphi_{j}$ do decrease as the horizon increases, as one might expect if the importance of deviations from the law of one price diminish over time. But clearly at the horizons relevant for the analysis of this paper, it is deviations from the law of one price that dominate real consumer exchange rates.

An alternative interpretation of these statistics is that the measured price of "traded" consumer goods is actually the price of a basket of goods and services. At the consumer level, prices reflect the marketing and transportation services that bring the good to the consumer. So, the variation in $x_{t}$, it 
might be argued, really reflects variation in the price of these nontraded services relative to the price of the traded commodity.

That is, $x_{t}$ can be further decomposed into two components in exactly the same way that $q_{t}$ was:

$$
x_{t}=d_{t}+u_{t} \text {. }
$$

Here, $d_{t}$ represents the (unobserved) true deviation from the law of one price for the traded commodity, and $u_{t}$ is the relative price of nontraded marketing services to traded commodity price in Mexico relative to the U.S.

Some evidence suggests that this explanation is not the right one. We would like to be able to calculate

$$
\tilde{\varphi}_{j}=\frac{\operatorname{Var}\left(d_{t+j}-d_{t}\right)}{\operatorname{Var}\left(q_{t+j}-q_{t}\right)} .
$$

Assume the true deviations from the law of one price, $d_{t}$, are uncorrelated with $u_{t}$ and $y_{t}$. Then,

$$
\boldsymbol{\theta}_{j} \equiv \frac{\left(\operatorname{Cov}\left(x_{t+j}-x_{t}, y_{t+j}-y_{t}\right)\right)^{2}}{\operatorname{Var}\left(y_{t+j}-y_{t}\right)}=\rho_{j}^{2} \operatorname{Var}\left(u_{t+j}-u_{t}\right)
$$

$\theta_{j}$ measures the "explained" variance in a regression of $x_{t+j}-x_{t}$ on $y_{t+j}-y_{t} \cdot \rho_{j}$ is the correlation coefficient between $u_{t+j}-u_{t}$ and $y_{t+j}-y_{t}$. (The measure of the $y_{t}$ component is derived from $x_{t}$ and $\left.q_{t}: y_{t}=q_{t}-x_{t}.\right)$

This statistic can be used in two ways to get a sense of how plausible the marketing story is. First, assume $\rho=1$, so that the relative price of nontraded marketing services to commodities is perfectly correlated with the general relative price of nontraded goods. Then, 


$$
\widetilde{\varphi}_{j}=\frac{\operatorname{Var}\left(x_{t+j}-x_{t}\right)-\boldsymbol{\theta}_{j}}{\operatorname{Var}\left(q_{t+j}-q_{t}\right)} .
$$

This statistic necessarily attributes less of the variance of the real exchange rate to deviations from the law of one price, compared to $\varphi_{j}$ plotted in Figure 1. But, it makes little difference. Figure 2 plots $\widetilde{\varphi}_{j}$. In constructing Figure 2, at the first four horizons, $\theta_{j}$ is set equal to zero. That is because at those horizons, $\operatorname{Cov}\left(x_{t+j}-x_{t}, y_{t+j}-y_{t}\right)$ is negative. This contradicts the underlying assumption of this exercise (that $d_{t}$ is uncorrelated with $u_{t}$ and $y_{t}$; and $u_{t}$ and $y_{t}$ are perfectly correlated.)

The lesson from Figure 2 is that if the relative price of nontraded marketing services behaves just like the relative price of other nontraded goods, it cannot be a very large component of $x_{t}$ since $\operatorname{Cov}\left(x_{t+j}-x_{t}, y_{t+j}-y_{t}\right)$ is quite small at all horizons.

Perhaps a fairer test of the marketing hypothesis would be to allow the correlation of $u_{t}$ and $y_{t}$ to be less than perfect. That correlation is not easily identified. But, note more generally

$$
\tilde{\varphi}_{j}=\frac{\operatorname{Var}\left(x_{t+j}-x_{t}\right)-\left(\theta_{j} / \rho_{j}^{2}\right)}{\operatorname{Var}\left(q_{t+j}-q_{t}\right)}
$$

The value of $\rho_{j}^{2}$ that makes the share of the variance of true deviations from the law of one price as small as one half can be backed out of this equation for each horizon $j$. Those are plotted in Figure 3 . They are all very small. The point is simply that if the explanation for Figure 1 is that "traded" prices measured in $x_{t}$ contain a large nontraded component from marketing and distribution, that component would have to be nearly uncorrelated with measured nontraded goods prices. Real exchange rate theories that rely on variation of nontraded marketing prices would need to rely on entirely different sources of shocks than the ones that drive measured nontraded goods prices. 
It appears more plausible to conclude that the simple interpretation of Figure 1 is the correct one: that most variation in real exchange rates in the short run comes from variation in traded goods prices across locations.

Since Mexican and U.S. consumer price indexes do not weight goods equally, might not the variance of $x_{t}$ be attributable to terms of trade changes? Evidence from subcategories of products suggest not. Let $a_{h t}$ be the weight of product $h$ in the traded goods price index for Mexico, and $a_{h t}^{*}$ be the weight for the same product in the U.S. price index. Then

$$
\begin{gathered}
p_{t}^{T}=a_{h} p_{t}^{h}+\sum_{i=1}^{k} a_{i} p_{t}^{i}, \quad i \neq h \\
p_{t}^{* T}=a_{h}^{*} p_{t}^{* h}+\sum_{i=1}^{k} a_{i}^{*} p_{t}^{*_{i}}, \quad i \neq h
\end{gathered}
$$

It follows that

$$
x_{t}=v_{t}^{h}+w_{t}^{h}
$$

where $x_{t}$ is defined as in equation (1.5), and

$$
\begin{gathered}
v_{t}^{h} \equiv s_{t}+p_{t}^{* h}-p_{t}^{h}, \\
w_{t}^{h} \equiv \sum_{i=1}^{k} a_{i}^{*}\left(p_{t}^{*_{i}}-p_{t}^{* h}\right)-\sum_{i=1}^{k} a_{i}\left(p_{t}^{i}-p_{t}^{h}\right) .
\end{gathered}
$$

If the law of one price holds for all goods, then $v_{t}^{h}=0$ and

$$
w_{t}^{h} \equiv \sum_{i=1}^{k}\left(a_{i}^{*}-a_{i}\right)\left(p_{t}^{i}-p_{t}^{h}\right)
$$

When the law of one price holds for all goods, changes in the real exchange rate only occur when the relative price of individual traded goods change, and those traded goods have different weights in the U.S. and Mexican price indexes. For example, if food has a higher weight in the Mexican traded 
consumer price index compared to the U.S., then an increase in the price of food relative to other traded goods will raise the Mexican traded consumer price index relative to that in the U.S.

If the law of one price holds, the statistic $\hat{\varphi}_{j}^{h}$, defined by

$$
\hat{\varphi}_{j}^{h}=\frac{\operatorname{Var}\left(v_{t+j}^{h}-v_{t}^{h}\right)}{\operatorname{Var}\left(x_{t+j}-x_{t}\right)}
$$

should be zero at all horizons. Conversely, if the law of one price does not hold, $\hat{\varphi}_{j}^{h}$ should be large for many goods.

Figure 4 plots $\hat{\varphi}_{j}^{h}$ for $j=1,2, \ldots 24$. The plots are for three categories of goods that are primarily traded: food, household furnishings, and apparel. The data sources and dates are the same as those described above.

The evidence from Figure 4 supports the presumption that movement in $x_{t}$ in the short run comes from deviations from the law of one price. At all horizons plotted, for all three categories of goods, $\hat{\varphi}_{j}^{h}$ is large - not at all close to zero.

Of course, it is possible that at some finer level of disaggregation, there are significant changes in relative traded goods prices within Mexico and the U.S. that are driving movements in $\hat{\varphi}_{j}^{h}$. At some level this is tautologically true: goods sold to consumers in Mexico and in U.S. are different goods because the location the good is sold is part of the characteristic of the good. But the statistics presented in Figures 1-4 limit the types of models of real exchange rate behavior one might appeal to if one rejects the interpretation that failures of the law of one price drive the real exchange rate.

Finally, if the law of one price fails, is it because of local-currency pricing? The models considered in this paper assume that for some goods there is local-currency pricing. That is, at least some producers set nominal prices in consumers' currencies. 
There are two pieces of evidence that appear to support the local-currency-pricing story. First is Rogers and Smith's (2000) study of consumer prices in Mexico, the U.S. and Canada. In their study, data on aggregate consumer prices for cities in those three countries is examined. They find that distance between cities explains much of the variation in relative price levels. That evidence supports the notion that the law of one price fails because of transportation costs and other real factors that drive a wedge between prices in different locations. But, even taking into account distance, relative price levels vary to a much greater degree for city pairs that lie across national borders than for city pairs that lie within a country. ${ }^{2}$ This evidence is consistent with the local-currency pricing effect. Indeed, the relative sizes of the U.S./Mexico, U.S./Canada, and Canada/Mexico border effects are nearly identical to the relative sizes of the nominal exchange rate variance for those countries.

Some simple direct evidence comes from examining the correlation of the nominal exchange rate with $x_{t}$. Figure 5 plots values of the correlation of $x_{t+j}-x_{t}$ with $s_{t+j}-s_{t}$. It shows that at horizons $j=1,2, \ldots 24$, the correlation is greater than 0.75 . At shorter horizons, the correlation exceeds 0.90. So, an approximately accurate description of the data is that $p_{t}^{T}$ and $p_{t}^{* T}$ are constant or very slow moving, while $s_{t}$ varies much more over time.

That does not necessarily imply that nominal prices are sticky, in the sense that they are not responding to forces of supply and demand. Perhaps it is the case that $p_{t}^{T}$ and $p_{t}^{* T}$ are relatively constant over time because monetary policy does a good job in stabilizing nominal prices. Under this theory, movement in $x_{t}$ really does represent changes in the real forces that segment Mexican and American markets. But this explanation has a curious implication. Since monetary policy is stabilizing $p_{t}^{T}$ and $p_{t}^{* T}$, the nominal exchange rate must do all of the adjustment in response to these

2 Rogers and Smith (2000) thus extends the analysis of Engel and Rogers (1996) to include Mexico, and finds similar results. Note however that Rogers and Smith (2000) uses only aggregate consumer prices, while Engel and Rogers (1996) 
changes in market segmentation. In short, it is a theory under which nominal exchange rate changes are entirely determined by transportation costs! This is an implausible alternative to the simple conclusion that $p_{t}^{T}$ and $p_{t}^{* T}$ are stable because consumer prices adjust more slowly than nominal exchange rates.

The data is consistent with the local-currency pricing assumption. Perhaps other models can explain the consumer price data as well, but, inescapably, they would be unusual theories.

\section{The Models}

In this section, we investigate two-country models. We label the countries Mexico and the United States. The models of this section assume that all goods produced are final consumer goods. The goods are produced in monopolistically competitive markets. In each country there are a large number of goods produced, each of which is an imperfect substitute for all other goods. Producers must set prices one period in advance.

As is well known from the menu-cost literature, the monopolistic assumption has several advantages for motivating sticky-price models in which output is demand-determined in the short run. In the first place, the notion that firms can set prices, in itself, implies some market power for producers. A producer in competitive markets must take market prices as given and cannot announce a price in advance. But monopolistic producers are able to set prices for their products, and may not change those preset prices in response to supply or demand shocks if there are menu costs and the size of the shocks is sufficiently small. Since producers are monopolists, they set prices above marginal costs. If there is an increase in demand for the product, the producer is willing to increase output to satisfy demand at preset prices as long as the increase in demand does not push into a region where 
marginal costs exceed the price. So, the monopolistic setting offers a rationale for demand-determined output. This "New Keynesian" approach also offers a rationale for macroeconomic policies that might stimulate output. Because monopolistic producers choose inefficiently low output levels, policies that can increase average output might be desirable.

The only source of uncertainty in these models is monetary uncertainty. It is straightforward to introduce other types of uncertainty - for example, uncertainty arising from productivity shocks or fiscal shocks. There are three reasons why we restrict attention to monetary shocks. First, the consensus of the papers of this conference is that the chief reason for Mexico to consider alternative monetary institutions is dissatisfaction with Mexico's control of monetary policy in recent years. Monetary shocks (perhaps arising from the banking sector) seem more significant than real productivity or spending shocks. Second, a major aim of this paper is to demonstrate how difficult it is to arrive at definitive conclusions about monetary policy in the absence of good emprical evidence on how goods prices are set and how agents can insure against foreign exchange rate changes. That point comes through even in models with only monetary shocks. Third, algebraically the model is complicated enough with only monetary shocks. Other shocks would make things worse.

\section{Households}

Households in Mexico are assumed to maximize expected utility over an infinite horizon. They get utility from consumption and from not working. The households maximize

$$
U_{t}=E_{t}\left(\sum_{s=t}^{\infty} \beta^{s-t} u_{s}\right), \quad 0<\beta<1
$$

where

$$
u_{s}=\frac{1}{1-\rho} Z_{s}^{1-\rho}-\frac{\eta}{2} L_{s}, \quad \rho>0 .
$$


$Z$ is defined by

$$
Z_{s}=\min \left(C_{s}, M_{s} / P_{s}\right)
$$

so that there are Leontief preferences over consumption and real balances. $C$ is a consumption index that is a geometric average of home and foreign consumption, $C_{M}$ and $C_{U} \cdot C_{M}$ receives a weight of $n$. There are $n$ identical individuals in Mexico, $0<n<1$, and $1-n$ identical individuals in the U.S., so the weight goods produced in each country receive in the utility function is equal to the populations proportions. In turn, $C_{M}$ and $C_{U}$ are indexes over continuums of goods produced in Mexico and the U.S., respectively. (Consumption of the good produced, for example, by firm $i$ in Mexico is $C_{M}(i)$.) There is a constant elasticity of substitution between goods produced within a country, $\lambda$, which is greater than 1. Note that following Corsetti and Pesenti's (1997) innovation to the Obstfeld and Rogoff (1995) framework, this utility function does not impose that the elasticity of substitution between goods produced within a country is the same as consumers' elasticity of substitution for goods produced in different countries. (See the Appendix for further discussion of the utility function of consumption.)

$L$ is the labor supply of the representative home agent. U.S. households have preferences similar to Mexicans'. They have identical preferences over Mexican and American-produced goods. Labor enters the utility function linearly, but of course Americans get disutility from their own labor. $P$ is the exact price index for Mexican consumption, so $P C$ equals total nominal spending in Mexico. The Leontief preferences imply:

$$
M_{t}=P_{t} C_{t}
$$

where $M$ are nominal peso balances. There is an analogous constraint for U.S. households, who perfer to hold U.S. dollars. 
We consider two extreme models of the menu of assets available to households. In the first, agents can neither borrow nor lend. The budget constraint for the typical Mexican is:

$$
P_{t} C_{t}+M_{t}=W_{t} L_{t}+\pi_{t}+M_{t-1}+T_{t}
$$

Agents are endowed with equal ownership in each of their own country's firms. $\pi_{t}$ is the representative agent's share of profits from Mexican firms. $T_{t}$ are monetary transfers from the government. $W_{t}$ is the wage rate.

In the second model, we assume there is a complete set of nominal state-contingent bonds available to all households in both countries. That is, there is an asset traded for each state of the world, but payoffs are settled in nominal terms. Agents must then use money payoffs to buy goods at the nominal prices that are set for them. See Devereux and Engel (1998) for details of this set-up.

\section{Firms}

Firms produce output using labor. The production function for a typical Mexican firm is given by:

$$
Y_{t}=L_{t}
$$

The objective of the Mexican firms is to set prices to maximize the expected utility of the firm owners. Mexican firms are owned by Mexican residents. Firms must set prices for period $t$ before any information on the stochastic variables - Mexican and American money supply and cost shocks - is known. No state-contingent pricing is allowed. As Obstfeld and Rogoff (1998) show, this problem can be expressed as maximizing the expected discounted value of profits using the consumption discount factor.

We consider the following models for pricing: 
1) Producer-currency pricing (PCP). Under this model, the Mexican firm sets prices in peso terms for sale to both Mexican and American consumers, and American firms set prices in dollars for sale to both sets of consumers. Of course, the price that Americans actually pay for Mexican goods is a dollar price, and that price varies instantaneously with changes in the nominal exchange rate. Likewise, the peso price that Mexicans pay for American goods varies with the exchange rate.

While, in principal, the Mexican firm could set a different peso price for sale to Mexicans and Americans, given the assumption of identical preferences it is clear it will choose the same ex ante price. Given the stationarity of the model, firm $i$ in Mexico chooses $P_{M t}(i)$ to maximize:

$$
E_{t-1}\left\{\left(\frac{\beta C_{t}^{-\rho} P_{t-1}}{P_{t} C_{t-1}^{-\rho}}\right)\left[\left(P_{M t}(i)-W_{t}\right)\left(X_{M t}(i)+X_{M t}^{*}(i)\right)\right]\right\}
$$

In this expression, $X_{M t}(i) \equiv n C_{M t}(i)$ represents total sales of the Mexican good to Mexicans, and $X_{M t}^{*}(i) \equiv(1-n) C_{M t}^{*}(i)$ are total sales of the Mexican good to Americans. American firms face an analogous problem. The optimal pricing rules are derived in the Appendix.

2) Local-currency pricing (LCP). In this model, the Mexican firm chooses a peso price for Mexican consumers and a dollar price for American consumers, ex ante. The prices are set one period in advance and do not change when the exchange rate changes. Likewise, American firms set a dollar price for American consumers and a peso price for Mexicans.

Firm $i$ in Mexico chooses $P_{M t}(i)$ (the price Mexicans pay for Mexican goods) and $P_{M t}^{*}(i)$ (the dollar price that Americans pay for Mexican goods) to maximize:

$$
E_{t-1}\left\{\left(\frac{\beta C_{t}^{-\rho} P_{t-1}}{P_{t} C_{t-1}^{-\rho}}\right)\left[P_{M t}(i) X_{M t}(i)+S_{t} P_{M t}^{*}(i) X_{M t}^{*}(i)-W_{t}\left(X_{M t}(i)+X_{M t}^{*}(i)\right)\right]\right\}
$$

In this expression, $S_{t}$ is the peso/dollar exchange rate. 
3) Mixed pricing. In this model, it is assumed that Mexican producers set a dollar price for U.S. consumers and a peso price for Mexican consumers, but U.S. producers set all prices in dollars. So, Mexican firms are LCP pricers, but U.S. firms are PCP pricers.

While the empirical evidence of section 1 indicates the law of one price does not hold for all goods, the data is not nearly refined enough to distinguish between pricing assumption (2) and (3). The mixed pricing assumption might be plausible given the commonly-held observation that depreciation of the peso helps Mexican producers relative to U.S. producers. Under the mixed pricing model, the price Mexicans pay for Mexican-produced goods is unaffected by exchange-rate changes but the peso price of U.S. goods increases when the peso depreciates.

\section{Equilibrium Relationships}

Under the assumption of no capital mobility (with no initial debts), trade must be balanced each period. Americans spend a fraction $n$ of their total spending on Mexican goods. So, the typical American spends $n P^{*} C^{*}$ dollars on Mexican goods. (Starred (*) variables represent U.S. quantities.) The peso value of those revenues is $n S P^{*} C^{*}$. (The exchange rate, $S$, is expressed as pesos per dollar.) Since there are $1-n$ Americans, the total peso value of exports to America from Mexico is $(1-n) n S P^{*} C^{*}$. Similarly, a typical Mexican spends $(1-n) P C$ on American imports, so the total peso value of imports is $(1-n) n P C$. Balanced trade, then, requires:

$$
P_{t} C_{t}=S_{t} P_{t}^{*} C_{t}^{*}
$$

Under the alternative assumption, there are complete nominal contingent claims, in which case:

$$
\frac{C_{t}^{-\rho}}{P_{t}}=\frac{C_{t}^{*-\rho}}{S_{t} P_{t}^{*}}
$$


Note that this expression is identical to the assumption of trade balance in the special case of logarithmic utility of consumption ( $\rho=1)$. However, while there is no consensus on a plausible value for the degree of relative risk aversion, almost all empirical studies (whether based on measures of risk aversion or intertemporal substitution) find $\rho>1$. We shall assume that is the case.

Another case in which these two equilibrium conditions are identical is when purchasing power parity $\left(P_{t}=S_{t} P_{t}^{*}\right)$ holds. As Obstfeld and Rogoff (1998) note, when purchasing power parity holds, and the elasticity of substitution between home and foreign goods is unity (as it is in this model), terms of trade changes effectively end up acting as an insurance device. There will be complete risk sharing, so that $C_{t}=C_{t}^{*}$, even if no assets are traded.

The logic follows that of Cole and Obstfeld (1991). Suppose there is a positive shock to the domestic money supply that lead it to increase by 1 percent. If there were no change in the exchange rate, spending by home residents would increase 1 percent (from the money demand equation, noting that $P$ is constant if the exchange rate does not change.) But the trade balance relationship shows that an increase in domestic consumption requires a depreciation of the domestic currency (holding $P$ and $P^{*}$ constant.) The depreciation of the home currency raises the price of foreign goods for home residents and lowers the price of home goods for foreign residents. The 1 percent increase in the money supply implies that the home price of foreign goods rises 1 percent. So the price increase contributes to a $1-n$ percent decline in domestic consumption. Combining the direct and indirect effects, domestic consumption ultimately rises only $1-(1-n)=n$ percent. Foreigners find the price of home goods drop 1 percent, so their spending rises $n$ percent. Thus, exchange-rate changes lead to fully insured consumption across countries.

Only in our PCP model of pricing does the law of one price apply to all goods, so it is the only model in which purchasing power parity holds. When there is local-currency pricing, changes in the 
exchange rate do not change the prices that households pay for goods. So, exchange rates do not play an insurance role.

Equilibrium in the market for Mexican goods requires supply equals demand:

$$
L_{t}=n C_{M t}+(1-n) C_{M t}^{*} \text {. }
$$

In the U.S. an analogous condition obtains.

\section{Government}

In each country, increases in money supply are transferred directly to residents. So, in Mexico,

$$
M_{t}=M_{t-1}+T_{t}
$$

A similar condition holds for the U.S.

We will assume that monetary policy in each country is independent of the other and the money supplies follow random walks:

$$
\begin{aligned}
& m_{t}-m_{t-1}=v_{t} . \\
& m_{t}^{*}-m_{t-1}^{*}=v_{t}^{*} .
\end{aligned}
$$

Lower case letters represent the natural $\log$ of upper-case letter. (E.g., $m_{t}=\ln \left(M_{t}\right)$.)

The i.i.d. shock, $v_{t}$, represents shocks to the money supply coming from disturbances, for example, in the banking system that the central bank cannot control. ${ }^{3}$ The presence of this type of shock is critical to the evaluation of fixed versus flexible exchange rate regimes. Mexico can eliminate the effects of these shocks on the local money supply by rigidly fixing the exchange rate relative to the dollar. To keep the exchange rate fixed, the money supply in Mexico must mimic the U.S. money

3 We assume both Mexican and U.S. monetary shocks are normally distributed. 
supply. So, by targeting the exchange rate, Mexico has an automatic mechanism to offset the effects of $v_{t}$ shocks on the money supply.

\section{Fixed or Floating Exchange Rates?}

With the exchange rate fixed at one, producers are essentially setting prices in the same currency for Americans and Mexicans. Given identical preferences, prices charged to each nation will be the same. That is, $P_{M t}(i)=P_{M t}^{*}(i)$, and $P_{U t}(i)=P_{U t}^{*}(i)$. If the law of one price holds for all goods, with identical preferences, purchasing power parity holds: $P_{t}=P_{t}^{*}$. With purchasing power parity, the trade-balance condition reduces to:

$$
C_{t}=C_{t}^{*} .
$$

Idiosyncratic risk is completely eliminated with fixed exchange rates because there are no longer any idiosyncratic shocks to money supplies. So one advantage of fixed exchange rates is the elimination of idiosyncratic risk.

We saw in the previous section that there was complete risk sharing in the PCP model of pricing (in which purchasing power parity holds), whether or not insurance markets exist. We can conclude that under that pricing scheme, the existence of capital markets does not matter for the fixed versus floating exchange rates question. Indeed, in the PCP case, the model is identical under no asset trade and complete insurance markets.

Actually, the fixed versus floating rate question is also not influenced by the completeness of markets in the case of complete local-currency pricing (LCP). Since prices of all goods are predetermined for consumers in each country, the price indexes do not change when there are monetary shocks. For example, $P_{t}$ is predetermined at time $t$. But, then from the money demand 
equation constraint, shocks to $C_{t}$ are completely determined by shocks to the home money supply, $M_{t}$. That relationship is true independent of any assumptions made about what assets can be traded. It does not matter if there is no asset trade, or the complete set of nominal contingent claims. The variance of consumption is simply equal to the variance of the money supply. (Note that because leisure enters utility linearly, households are only risk averse with respect to consumption.)

Why does the absence of asset trade not have any effect on the risk from consumption? The answer is that the complete set of nominal contingent claims in this case provides no consumption insurance. Because we have assumed that all contracts must be written in nominal terms, the contingent claims do not explicitly provide for real insurance. The optimal contract implies that the marginal value of a peso is the same for Mexicans and Americans in all states of nature. But that provides no consumption insurance in this model. Suppose the Mexican peso money supply increases in some state. Then, the peso depreciates relative to the dollar. This means, given the fixity of nominal prices, that goods are cheaper in Mexico than in the U.S. Hence, the optimal contract will call for Mexicans to have higher consumption in that state (until the marginal value of a peso is equalized.) Mexican consumption rises when the Mexican money supply does. Under our assumptions, it rises one-for-one, and there is no consumption insurance.

So, in the two extreme models of goods pricing - PCP and LCP - the completeness of financial markets has no bearing on the fixed versus floating decision. That is because under PCP there effectively is complete risk sharing whether or not assets are traded, while under LCP there is no risk sharing whether or not assets are traded. Of course, these extreme results arise in part because of our assumptions on preferences, but this is an excellent illustration of the interaction between the assumptions on completeness of financial markets and goods pricing.

In the model of mixed pricing (U.S. producers set prices in dollars, Mexican producers set prices in pesos for Mexican residents and dollars for U.S. residents), part of the appeal of fixed 
exchange rates is the elimination of idiosyncratic risk. That effect is different under no asset trade than when there are complete nominal contingent bonds. Of course, fixed exchange rates do not eliminate all risk. There is still risk in the system from shocks to the U.S. money supply. Moreover, welfare maximization is not equivalent to risk minimization. As Obstfeld and Rogoff (1998) and Devereux and Engel (1998) discuss, the properties of the stochastic processes that determine monetary policy can influence expected levels of consumption and leisure, as well as their variances. (We assume shocks to the log of the money supply are normally distributed, so the first two moments describe the entire distribution.) The Appendix derives the conditions under which floating or fixed rates provide the highest welfare for Mexico.

Under mixed pricing, floating rates are preferred to fixed exchange rates if there is no international trade in assets when:

$$
\frac{\sigma_{v}^{2}}{\sigma_{v^{*}}^{2}}<\frac{\rho+(\rho-1)(1-n)}{\rho-(\rho-1)(1-n)}
$$

Under the assumption of complete nominal contingent claims, floating rates are preferred if:

$$
\frac{\sigma_{v}^{2}}{\sigma_{v^{*}}^{2}}<1
$$

Under both cases, floating rates are more likely to be best when home money shocks have a small variance. Of course, by this standard, Mexico is not a strong candidate for floating rates. Under complete nominal contingent bond markets, Mexico should opt for fixed exchange rates as long as the U.S. monetary variance is lower than the Mexican

But, when there is no asset trade, the condition is subtler. If Mexico were very large (so $n$ approaches unity) compared to the U.S., the condition (3.1) approaches the same condition as (3.2). 
But, in fact, Mexico is relatively small. As $n$ goes to zero, condition (3.2) implies that floating rates in Mexico are preferred as long as:

$$
\frac{\sigma_{v}^{2}}{\sigma_{v^{*}}^{2}}<2 \rho-1
$$

The surprising thing here is that the more risk averse agents are, the more likely they are to prefer floating exchange rates. This may seem puzzling because fixed exchange rates eliminate idiosyncratic risk, and would therefore seem to be more desirable for more risk averse agents.

The answer to this puzzle comes from noting that for given variances of Mexican and U.S. money supplies, floating exchange rates tend to reduce aggregate risk (while leading to some idiosyncratic risk.) To understand this, note that the log of the Mexican price index can be written as:

$$
p_{t}=n p_{m t}+(1-n)\left(s_{t}+\tilde{p}_{u t}\right)
$$

In this notation, (in logs) the aggregate price index, $p_{t}$, is a weighted average of the price of Mexican goods, $p_{m t}$, and American goods, $s_{t}+\tilde{p}_{u t}$. The price of American goods is set in dollars at $\tilde{p}_{u t}$, and varies with the exchange rate, $s_{t}$. Since $p_{m t}$ and $\tilde{p}_{u t}$ are preset, the conditional variance of the Mexican price level is equal to $(1-n)^{2}$ times the variance of the exchange rate. But, given that nominal spending in each of Mexico and the U.S. is equal to the money supply in each country (from the money demand equations), the trade balance condition implies that the exchange rate is simply equal to the relative money supplies. In log terms:

$$
s_{t}=m_{t}-m_{t}^{*}
$$

The money demand equations along with equations (3.3) and (3.4) gives us:

$$
c_{t}=n m_{t}+(1-n) m_{t}^{*}-n p_{m t}-(1-n) \tilde{p}_{u t} .
$$


It follows that under floating rates, when $m_{t}$ and $m_{t}^{*}$ are uncorrelated:

$$
\operatorname{Var}_{t-1}\left(c_{t}\right)=n^{2} \sigma_{v}^{2}+(1-n)^{2} \sigma_{v^{*}}^{2}
$$

Under fixed exchange rates,

$$
\operatorname{Var}_{t-1}\left(c_{t}\right)=\sigma_{v^{*}}^{2}
$$

Since the "weights" in expression (3.6) sum to less than one, Mexican monetary variance could be larger than American monetary variance under floating rates, but the variance of consumption could still be lower than under fixed exchange rates. As $n$ declines, Mexican monetary variance can be quite large, and still floating rates deliver a smaller consumption variance. Indeed, comparing equations (3.6) and (3.7), the condition for floating rates to yield a smaller consumption variance than fixed exchange rates is:

$$
\frac{\sigma_{v}^{2}}{\sigma_{v^{*}}^{2}}<\frac{2-n}{n}
$$

So, even though there is idiosyncratic risk under floating rates and none under fixed exchange rates, the total risk facing Mexicans may be smaller under floating rates - even if the variance of Mexican money supply shocks is quite large compared to that of U.S. money supply shocks.

This helps explain the finding that floating rates become more likely to be preferred to fixed exchange rates the greater the degree of risk-aversion. Intuitively, under floating exchange rates the real money supply is less volatile than the nominal money supply if there is any pass-through of the exchange rate to prices. An increase in $M$ results in a depreciation of the domestic currency. If that pushes up the price of imported goods, $P$ rises as well, so $M / P$ is more stable than $M$.

Note that it is not simply the variance of consumption that matters for the choice of exchangerate regime. Equation (3.1) gives the condition under which floating exchange rates are welfare- 
maximizing under no capital mobility, while equation (3.8) is the condition for consumption-variance minimization. As we noted, monetary policy can influence the expected levels of consumption and leisure. The two conditions can lead to widely different implications. Indeed, equation (3.1) is always a more stringent condition than equation (3.8). Taking into account the effects on expected levels of consumption and leisure, the case for fixed exchange rates is always stronger than if we just consider the variance of consumption.

The relevance of this point is that if our approach to analyzing welfare were to linearize the model around the steady state, as is commonly done in "calibrated" equilibrium macroeconomic models, the welfare criterion would only take into account the variance of consumption in this model. The expected levels of consumption and leisure are affected by short-run effects of monetary variance on price levels that would be ignored under the linearization approach. Since the criterion for choosing fixed or floating rates in this model can be widely different if one takes into account the full welfaremaximizing expression versus the minimum-variance condition, one must be wary in general of the conclusions from the calibrated linearized models.

Table 1 presents the conditions under which floating exchange rates are preferred to fixed exchange rates in each of our models, under each assumption about completeness of asset markets. As we have noted, under PCP and LCP, the criteria do not depend on what assets are traded. We note that equation (3.1) is the welfare criterion under PCP, while equation (3.2) is the criterion under LCP.

Table 1 also presents the conditions under which floating rates are preferred if we mistakenly only paid attention to the minimum-consumption-variance measure. It is interesting to note that whenever there is any pass-through of exchange rates to prices (in the mixed pricing model or the LCP model), the welfare condition for choosing floating exchange rates is more stringent than the minimum-consumption-variance condition. The implication is that fixed exchange rates reduce the monopoly distortion in prices (as discussed in Devereux and Engel (1998)) and therefore increase 
expected levels of consumption. Taking into account the effects on levels, the case for fixed exchange rates is stronger.

\section{Conclusions}

The empirical evidence presented in section 1 is suggestive but far from definitive. The indication from this preliminary look at the data is that deviations from the law of one price for consumer goods in Mexico is large, and that there may be some local-currency pricing. The responsiveness of consumer prices to exchange rates is not complete, but more work is required to understand the nature of the price-adjustment process in Mexico.

The model section underscores the importance of this empirical work. The stabilizing properties of exchange-rate regimes, and the effects of exchange-rate regime on the efficiency level of the economy, are dependent on the nature of price setting. Furthermore, the type of price-setting behavior interacts with the completeness of financial markets. We have seen that if the law of one price holds for all goods, then there is complete consumption insurance even in the absence of any asset trade. In absolute contrast, if there is complete local-currency pricing, there is no consumption insurance even if there is a complete set of nominal contingent bonds traded.

The models considered here are, in many ways, very simple and too crude to "calibrate" and come up with a precise measure of the gains from fixing the exchange rate, for example. The models can only make suggestions about some of the things that policy-makers should consider in choosing an exchange rate regime. This paper emphasizes the role of price setting and capital mobility. There are other factors that surely are important as well.

So, what are the intuitive lessons from the models of this paper?

1) Of course, permanently fixed exchange rates are more likely to be desirable for a country if it has little control otherwise of its own monetary conditions. 
2) The degree of capital mobility may or may not matter for the choice of exchange-rate regime, depending on how goods prices are set. While fixing the exchange rate may reduce or eliminate idiosyncratic risk among countries, the overall risk for the country fixing its exchange rate may not be affected or may be increased.

3) There is an automatic stabilizing property to flexible exchange rates even when the only shocks are monetary shocks, if there is any exchange-rate pass-through.

4) The choice of exchange-rate regime could affect the degree of monopolistic inefficiency in the economy.

Not all of these conclusions, of course, are new. The first point is a standard in the exchangerate literature, and the third point is implicit in some of the papers produced in the 1980s. (However, all of this literature presumes complete pass-through of exchange rates to consumer prices.) The second and the fourth points are new insights that arise from the new open-economy macroeconomics. Further research is needed to assess their importance.

The empirical evidence for Mexico suggests that the model of mixed pricing and imperfect insurance may be the most useful in assessing the benefits of permanently fixing exchange rates to the U.S. dollar (perhaps through dollarization.) Mexican monetary policy has been less stable that U.S. monetary policy, so it would seem that adopting U.S. monetary policy would automatically make consumption more stable. But this paper raises some doubt on that issue. Floating rates have an automatic stabilizing property that reduce the volatility of monetary shocks when there is a high degree of pass through of exchange rates to import prices. Unfortunately, our empirical analysis is not refined enough to determine how large is the pass-through of exchange rates to final goods prices in Mexico. The less pass-through there is to final goods prices, the stronger the case for a more fixed exchange rate. 
Finally, note that the decision of which currency to set prices in may well depend on the exchange rate regime and the completeness of capital markets. That decision is exogenous in the models of this paper, but one might hypothesize that volatile floating exchange rates discourage consumer-currency pricing when there are few opportunities to hedge risk. 


\section{References}

Bacchetta, Philippe, and Eric van Wincoop, 1998, Does exchange rate stability increase trade and capital flows, Federal Reserve Bank of New York, working paper no. 9818.

Bacchetta, Philippe, and Eric van Wincoop, 2000, Capital flows to emerging markets: Liberalization, overshooting and volatility, in Sebastian Edwards, ed., Capital Flows and the Emerging Economies (Chicago: University of Chicago and NBER).

Betts, Caroline and Michael B. Devereux, 1996, The exchange rate in a model of pricing-to-market, European Economic Review 40, 1007-1021.

Betts, Caroline, and Michael B. Devereux, 2000, Exchange rate dynamics in a model of pricing-tomarket, Journal of International Economics 50, 215-244.

Buiter, Willem, 1999, The EMU and the NAMU: What is the case for North American Monetary Union?, Canadian Journal of Economics, forthcoming.

Calvo, Guillermo, 1999, On dollarization, University of Maryland, working paper.

Calvo, Guillermo, 2000, Capital markets and the exchange rate: With special reference to the dollarization debate, paper presented at conference on "Global Monetary Integration” at the Federal Reserve Bank of Cleveland, May 31 - June 2, 2000.

Calvo, Guillermo; Leonardo Leiderman; and, Carmen R. Reihnart, 1996, Inflows of capital to developing countries in the 1990s, Journal of Economic Perspectives 10, 123-139.

Chari, V.V.; Patrick J. Kehoe; and, Ellen McGrattan, 2000, Can sticky price models generate volatile and persistent real exchange rates?, Federal Reserve Bank of Minneapolis, Staff Report 277.

Cole, Harold L., and Maurice Obstfeld, 1991, Commodity trade and international risk sharing: How much do financial markets matter?, Journal of Monetary Economics 23, 377-400. 
Cooley, Thomas F. and Vincent Quadrini, 1999, The costs of losing monetary independence: The case of Mexico, paper presented at the conference on "Global Monetary Integration" at the Federal Reserve Bank of Cleveland, May 31 - June 2, 2000.

Corsetti, Giancarlo, and Paolo Pesenti, 1997, Welfare and macroeconomic interdependence, National Bureau of Economic Research, working paper no. 6307.

Devereux, Michael B., and Charles Engel, 1998, Fixed vs. floating exchange rates: How price setting affects the optimal choice of exchange-rate regime, National Bureau of Economic Research, working paper no. 6867.

Devereux, Michael B.; Engel, Charles; and, Cedric Tille, 1999, Exchange rate pass-through and the welfare effects of the euro, National Bureau of Economics, working paper no. 7382.

Eichengreen, Barry, and Ashoka Mody, 2000, What explains changing spreads on emerging market debt?, in Sebastian Edwards, ed., Capital Flows and the Emerging Economies (Chicago: University of Chicago and NBER).

Engel, Charles, 1999, Accounting for U.S. real exchange rate changes, Journal of Political Economy 107, 507-538.

Engel, Charles, and John H. Rogers, 1996, How wide is the border?, American Economic Review 86, $1112-1125$.

Friedman, Milton, 1953, The case for flexible exchange rates, in Essays in Positive Economics (Chicago: University of Chicago Press), 157-203.

Ghosh, Swati, and Holger Wolf, 2000, Is there a curse of location? Spatial determinants of capital flows to emerging markets, in Sebastian Edwards, ed., Capital Flows and the Emerging Economies (Chicago: University of Chicago and NBER).

Hau, Harald, 2000, Exchange rate determination: The role of factor price rigidities and nontradeables, Journal of International Economics 50, 421-447. 
Mendoza, Enrique G., 2000, Credit-market frictions, policy-credibility and the business cycle of emerging markets, paper presented at the conference on "Global Monetary Integration" at the Federal Reserve Bank of Cleveland, May 31 - June 2, 2000.

Mundell, Robert A., 1960, The monetary dynamics of international adjustment under fixed and floating exchange rates, Quarterly Journal of Economics 74, 227-257.

Mundell, Robert A., 1961, Flexible exchange rates and employment policy, Canadian Journal of Economics and Political Science 27, 509-517.

Mundell, Robert A., 1963, Capital mobility and stabilization policy under fixed and flexible exchange rates, Canadian Journal of Economics and Political Science 29, 475-485.

Obstfeld, Maurice and Kenneth Rogoff, 1995, Exchange rate dynamics redux, Journal of Political Economy 103, 624-660.

Obstfeld, Maurice and Kenneth Rogoff, 1996, Foundations of International Macroeconomics (Cambridge: MIT Press).

Obstfeld, Maurice and Kenneth Rogoff, 1998, Risk and exchange rates, National Bureau of Economic Research, working paper no. 6694.

Obstfeld, Maurice and Kenneth Rogoff, 2000, New directions for stochastic open economy models, Journal of International Economic 50, 117-153.

Rankin, Neil, 1998, Nominal rigidity and monetary uncertainty in a small open economy, Journal of Economic Dynamics and Control 22, 679-702.

Rogers, John H., and Hayden P. Smith, 2000, Border effects within the Nafta countries, Board of Governors of the Federal Reserve System, manuscript.

Schmitt-Grohé, Stephanie and Martin Uríbe, 2000, Stabilization policy and the costs of dollarization, paper presented at the conference on "Global Monetary Integration" at the Federal Reserve Bank of Cleveland, May 31 - June 2, 2000. 


\section{Table 1}

\section{Criteria for Floating versus Fixed Exchange Rates}

\begin{tabular}{|c|c|c|}
\hline & Welfare & Consumption Variance \\
\hline Mixed pricing, trade balance & $\frac{\rho+(\rho-1)(1-n)}{\rho-(\rho-1)(1-n)}$ & $\frac{2-n}{n}$ \\
\hline Mixed pricing, complete & 1 & $\frac{n+2 \rho(1-n)}{n}$ \\
\hline Local-currency, trade balance & 1 & 1 \\
\hline Local-currency, complete & 1 & 1 \\
\hline Producer-currency pricing & $\frac{\rho+(\rho-1)(1-n)}{\rho-(\rho-1)(1-n)}$ & $\frac{2-n}{n}$ \\
\hline
\end{tabular}

Notes: Floating exchange rates are preferred to fixed exchange rates if $\frac{\sigma_{v}^{2}}{\sigma_{v^{*}}^{2}}$ is less than the entry in each cell. "Mixed pricing" refers to the case in which U.S. producers set all prices in dollars, and Mexican producers set prices for Mexican households in pesos and for U.S households in dollars. "Local-currency" refers to the case in which all prices are set in the households' currency. "Producercurrency pricing" refers to the case in which all prices are set in the producers' currency. "Trade balance" refers to the assumption of no asset trade, so trade is always balanced. "Complete" refers to the assumption of a complete set of state-contingent bonds. Note that under producer-currency pricing the criteria are the same under trade balance and complete bonds. "Welfare" refers to using expected utility as the criteria for choosing between floating and fixed exchange rates. "Consumption variance" refers to using minimum consumption variance as the criterion for choosing the exchange-rate system 


\section{Appendix}

\section{Households}

$C$ is a consumption index that is a geometric average of home and foreign consumption:

$$
C=\frac{C_{M}^{n} C_{U}^{1-n}}{n^{n}(1-n)^{1-n}}
$$

$C_{M}$ and $C_{U}$ are indexes over consumption of goods produced in Mexico and the U.S., respectively:

$$
C_{M}=\left[n^{-1 / \lambda} \int_{0}^{n} C_{M}(i)^{\lambda-1 / \lambda} d i\right]^{\lambda / \lambda-1} \quad C_{U}=\left[(1-n)^{-1 / \lambda} \int_{n}^{1} C_{U}(i)^{\lambda-1 / \lambda} d i\right]^{\lambda / \lambda-1}
$$

The optimal within-period consumption choices can be summarized by:

$$
\begin{array}{cc}
C_{M}(i)=\frac{1}{n}\left[\frac{P_{M}(i)}{P_{M}}\right]^{-\lambda} C_{M} & C_{U}(i)=\frac{1}{1-n}\left[\frac{P_{U}(i)}{P_{U}}\right]^{-\lambda} C_{U} \\
P_{M} C_{M}=n P C & P_{U} C_{U}=(1-n) P C \\
\int_{0}^{n} P_{M}(i) C_{M}(i) d i=P_{M} C_{M} & \int_{n}^{1} P_{U}(i) C_{U}(i) d i=P_{U} C_{U}
\end{array}
$$

The price index, $P$, used to deflate nominal balances is the exact price index associated with the consumption part of the utility function. So, $P$ is defined by

$$
P=P_{M}^{n} P_{U}^{1-n}
$$

where 


$$
P_{M}=\left[\frac{1}{n} \int_{0}^{n} P_{M}(i)^{1-\lambda} d i\right]^{1 / 1-\lambda}
$$

$P_{U}=\left[\frac{1}{1-n} \int_{n}^{1} P_{U}(i)^{1-\lambda} d i\right]^{1 / 1-\lambda}$

The consumption-leisure trade-off is captured by the first-order condition:

$$
\frac{W_{t}}{P_{t} C_{t}^{\rho}}=\eta
$$

(Recall that a unit of real balances must accompany an additional unit of consumption.)

\section{Firms}

There are three sets of pricing assumptions: mixed, PCP and LCP. For each of these, we can derive expressions for the prices of goods from the optimization problem of firms. It is then useful to simplify the expressions using either the trade balance condition (with no trade in assets) or the risksharing condition (with complete nominal claims.)

$P_{M t}$ is the peso price paid by Mexicans for Mexican-produced goods. $P_{M t}^{*}$ is the dollar price paid by Americans for Mexican-produced goods. $P_{U t}$ is the dollar price paid by Americans for American-produced goods. $P_{U t}^{*}$ is the peso price paid by Mexicans for American-produced goods. 


\section{Mixed}

\begin{tabular}{|c|c|}
\hline$P_{M t}$ & $\frac{\lambda}{\lambda-1 \frac{E_{t-1}\left(W_{t} C_{t}^{1-\rho}\right)}{E_{t-1}\left(C_{t}^{1-\rho}\right)}}$ \\
\hline$P_{M t}^{*}$ & $\frac{\lambda}{\lambda-1 \frac{E_{t-1}\left(W_{t} C_{t}^{*} C_{t}^{-\rho} P_{t}^{*} / P_{t}\right)}{E_{t-1}\left(S_{t} C_{t}^{*} C_{t}^{-\rho} P_{t}^{*} / P_{t}\right)}}$ \\
\hline$P_{U t}$ & $S_{t} \frac{\lambda}{\left.\lambda-1 \frac{E_{t-1}\left(W_{t}^{*} C_{t} C_{t}^{*-\rho} P_{t} / S_{t} P_{t}^{*}\right)}{E_{t-1}\left(C_{t} C_{t}^{*}-\rho\right.} P_{t} / S_{t} P_{t}^{*}\right)}$ \\
\hline$P_{U t}^{*}$ & $\frac{\lambda}{\lambda-1} \frac{E_{t-1}\left(W_{t}^{*} C_{t}^{* 1-\rho}\right)}{E_{t-1}\left(C_{t}^{* 1-\rho}\right)}$ \\
\hline
\end{tabular}

Imposing the appropriate equilibrium condition, and using condition (A.2), the equations for prices reduce to:

\begin{tabular}{|c|c|c|}
\hline & Trade Balance & Complete Markets \\
\hline$P_{M t}$ & $\frac{\lambda \eta}{\lambda-1} \frac{E_{t-1}\left(P_{t} C_{t}\right)}{E_{t-1}\left(C_{t}^{1-\rho}\right)}$ & $\frac{\lambda \eta}{\lambda-1} \frac{E_{t-1}\left(P_{t} C_{t}\right)}{E_{t-1}\left(C_{t}^{1-\rho}\right)}$ \\
\hline$P_{M t}^{*}$ & $\frac{\lambda \eta}{\lambda-1} \frac{E_{t-1}\left(P_{t}^{*} C_{t}^{*}\right)}{E_{t-1}\left(C_{t}^{1-\rho}\right)}$ & $\frac{\lambda \eta}{\lambda-1} \frac{E_{t-1}\left(P_{t}^{*} C_{t}^{*}\right)}{E_{t-1}\left(C_{t}^{* 1-\rho}\right)}$ \\
\hline$P_{U t}$ & $\frac{\lambda \eta}{\lambda-1} S_{t} \frac{E_{t-1}\left(P_{t}^{*} C_{t}^{*}\right)}{E_{t-1}\left(C_{t}^{* 1-\rho}\right)}$ & $\frac{\lambda \eta}{\lambda-1} S_{t} \frac{E_{t-1}\left(P_{t} C_{t} / S_{t}\right)}{E_{t-1}\left(C_{t}^{* 1-\rho}\right)}$ \\
\hline$P_{U t}^{*}$ & $\frac{\lambda \eta}{\lambda-1} \frac{E_{t-1}\left(P_{t}^{*} C_{t}^{*}\right)}{E_{t-1}\left(C_{t}^{* 1-\rho}\right)}$ & $\frac{\lambda \eta}{\lambda-1} \frac{E_{t-1}\left(P_{t}^{*} C_{t}^{*}\right)}{E_{t-1}\left(C_{t}^{* 1-\rho}\right)}$ \\
\hline
\end{tabular}




\section{PTM}

\begin{tabular}{|c|c|}
\hline$P_{M t}$ & $\frac{\lambda}{\lambda-1} \frac{E_{t-1}\left(W_{t} C_{t}^{1-\rho}\right)}{E_{t-1}\left(C_{t}^{1-\rho}\right)}$ \\
\hline$P_{M t}^{*}$ & $\frac{\lambda}{\lambda-1} \frac{E_{t-1}\left(W_{t} C_{t}^{*} C_{t}^{-\rho} P_{t}^{*} / P_{t}\right)}{E_{t-1}\left(S_{t} C_{t}^{*} C_{t}^{-\rho} P_{t}^{*} / P_{t}\right)}$ \\
\hline$P_{U t}$ & $\frac{\lambda}{\lambda-1} \frac{E_{t-1}\left(W_{t}^{*} C_{t} C_{t}^{*-\rho} P_{t} / P_{t}^{*}\right)}{E_{t-1}\left(C_{t} C_{t}^{*-\rho} P_{t} / S_{t} P_{t}^{*}\right)}$ \\
\hline$P_{U t}^{*}$ & $\frac{\lambda}{\lambda-1} \frac{E_{t-1}\left(W_{t}^{*} C_{t}^{* 1-\rho}\right)}{E_{t-1}\left(C_{t}^{*}-\rho\right)}$ \\
\hline
\end{tabular}

Imposing the appropriate equilibrium condition, and using condition (A.2), the equations for prices reduce to:

\begin{tabular}{|c|c|c|}
\hline & Trade Balance & Complete Markets \\
\hline$P_{M t}$ & $\frac{\lambda \eta}{\lambda-1} \frac{E_{t-1}\left(P_{t} C_{t}\right)}{E_{t-1}\left(C_{t}^{1-\rho}\right)}$ & $\frac{\lambda \eta}{\lambda-1} \frac{E_{t-1}\left(P_{t} C_{t}\right)}{E_{t-1}\left(C_{t}^{1-\rho}\right)}$ \\
\hline$P_{M t}^{*}$ & $\frac{\lambda \eta}{\lambda-1} \frac{E_{t-1}\left(P_{t}^{*} C_{t}^{*}\right)}{E_{t-1}\left(C_{t}^{1-\rho}\right)}$ & $\frac{\lambda \eta}{\lambda-1} \frac{E_{t-1}\left(P_{t}^{*} C_{t}^{*}\right)}{E_{t-1}\left(C_{t}^{* 1-\rho}\right)}$ \\
\hline$P_{U t}$ & $\frac{\lambda \eta}{\lambda-1} \frac{E_{t-1}\left(P_{t} C_{t}\right)}{E_{t-1}\left(C_{t}^{* 1-\rho}\right)}$ & $\frac{\lambda \eta}{\lambda-1} \frac{E_{t-1}\left(P_{t} C_{t}\right)}{E_{t-1}\left(C_{t}^{1-\rho}\right)}$ \\
\hline$P_{U t}^{*}$ & $\frac{\lambda \eta}{\lambda-1} \frac{E_{t-1}\left(P_{t}^{*} C_{t}^{*}\right)}{E_{t-1}\left(C_{t}^{*-\rho}\right)}$ & $\frac{\lambda \eta}{\lambda-1} \frac{E_{t-1}\left(P_{t}^{*} C_{t}^{*}\right)}{E_{t-1}\left(C_{t}^{*-\rho}\right)}$ \\
\hline
\end{tabular}




\section{PCP}

\begin{tabular}{|c|c|}
\hline$P_{M t}$ & $\frac{\lambda \eta}{\lambda-1} \frac{E_{t-1}\left(P_{t} C_{t}\right)}{E_{t-1}\left(C_{t}^{1-\rho}\right)}$ \\
\hline$P_{M t}^{*}$ & $\frac{\lambda \eta}{\lambda-1} \frac{1}{S_{t}} \frac{E_{t-1}\left(P_{t} C_{t}\right)}{E_{t-1}\left(C_{t}^{1-\rho}\right)}$ \\
\hline$P_{U t}$ & $S_{t} \frac{\lambda}{\lambda-1} \frac{E_{t-1}\left(W_{t}^{*} C_{t} C_{t}^{*-\rho} P_{t} / S_{t} P_{t}^{*}\right)}{E_{t-1}\left(C_{t} C_{t}^{*-\rho} P_{t} / S_{t} P_{t}^{*}\right)}$ \\
\hline$P_{U t}^{*}$ & $\frac{\lambda}{\lambda-1} \frac{E_{t-1}\left(W_{t}^{*} C_{t}^{* 1-\rho}\right)}{E_{t-1}\left(C_{t}^{* 1-\rho}\right)}$ \\
\hline
\end{tabular}

Imposing the appropriate equilibrium condition, and using condition (A.2), the equations for prices reduce to (recognizing that trade balance and complete markets are equivalent):

\begin{tabular}{|c|c|}
\hline$P_{M t}$ & $\frac{\lambda}{\lambda-1} \frac{E_{t-1}\left(W_{t} C_{t}^{1-\rho}\right)}{E_{t-1}\left(C_{t}^{1-\rho}\right)}$ \\
\hline$P_{M t}^{*}$ & $\frac{\lambda}{\lambda-1} \frac{1}{S_{t}} \frac{E_{t-1}\left(W_{t} C_{t}^{*} C_{t}^{-\rho} P_{t}^{*} S_{t} / P_{t}\right)}{E_{t-1}\left(S_{t} C_{t}^{*} C_{t}^{-\rho} P_{t}^{*} / P_{t}\right)}$ \\
\hline$P_{U t}$ & $\frac{\lambda \eta}{\lambda-1} S_{t} \frac{E_{t-1}\left(P_{t}^{*} C_{t}^{*}\right)}{E_{t-1}\left(C_{t}^{* 1-\rho}\right)}$ \\
\hline$P_{U t}^{*}$ & $\frac{\lambda \eta}{\lambda-1} \frac{E_{t-1}\left(P_{t}^{*} C_{t}^{*}\right)}{E_{t-1}\left(C_{t}^{*-\rho}\right)}$ \\
\hline
\end{tabular}




\section{Solutions}

\section{Mixed, Trade Balance}

$$
\left(P_{M t}^{*}\right)^{n}\left(P_{U t}^{*}\right)^{1-n}=P_{t}^{*}=\frac{\lambda \eta}{\lambda-1}\left[\frac{E_{t-1}\left(P_{t}^{*} C_{t}^{*}\right)}{E_{t-1}\left(C_{t}^{1-\rho}\right)}\right]^{n}\left[\frac{E_{t-1}\left(P_{t}^{*} C_{t}^{*}\right)}{E_{t-1}\left(C_{t}^{* 1-\rho}\right)}\right]^{1-n} .
$$

Since $P_{t}^{*}$ is predetermined at time $t$, this expression reduces to

$$
\left(E_{t-1} C_{t}^{1-\rho}\right)^{n}\left(E_{t-1} C_{t}^{* 1-\rho}\right)^{1-n}=\frac{\lambda \eta}{\lambda-1} E_{t-1} C_{t}^{*}
$$

Using log-normality, this can be written as:

$n(1-\rho) E c+n \frac{(1-\rho)^{2}}{2} \sigma_{c}^{2}+(1-n)(1-\rho) E c^{*}+(1-n) \frac{(1-\rho)^{2}}{2} \sigma_{c^{*}}^{2}=\ln \left(\frac{\lambda \eta}{\lambda-1}\right)+E c^{*}+\frac{1}{2} \sigma_{c^{*}}^{2}$

We can write:

$$
P_{M t}=\frac{\lambda \eta}{\lambda-1} P_{t} S_{t}^{n-1} \frac{E_{t-1}\left(S_{t}^{1-n} C_{t}\right)}{E_{t-1}\left(C_{t}^{1-\rho}\right)}
$$

Also:

$$
P_{U t}=\frac{\lambda \eta}{\lambda-1} P_{t} S_{t}^{n} \frac{E_{t-1}\left(S_{t}^{-n} C_{t}\right)}{E_{t-1}\left(C_{t}^{* 1-\rho}\right)}
$$

So

$$
\left(P_{M t}\right)^{n}\left(P_{u t}\right)^{1-n}=P_{t}=\frac{\lambda \eta}{\lambda-1} P_{t}\left[\frac{E_{t-1}\left(S_{t}^{1-n} C_{t}\right)}{E_{t-1}\left(C_{t}^{1-\rho}\right)}\right]^{n}\left[\frac{E_{t-1}\left(S_{t}^{-n} C_{t}\right)}{E_{t-1}\left(C_{t}^{* 1-\rho}\right)}\right]^{1-n}
$$

In this model,

$$
S_{t}=M_{t} / M_{t}^{*}
$$


so, we get

$$
\left[E_{t-1}\left(C_{t}^{1-\rho}\right)\right]^{n}\left[E_{t-1}\left(C_{t}^{* 1-\rho}\right)\right]^{1-n}=\frac{\lambda \eta}{\lambda-1}\left[E_{t-1}\left(\left(\frac{M_{t}}{M_{t}^{*}}\right)^{1-n} C_{t}\right)\right]^{n}\left[E_{t-1}\left(\left(\frac{M_{t}}{M_{t}^{*}}\right)^{-n} C_{t}\right)\right]^{1-n}
$$

The left-hand side of this equation is equal to $\frac{\lambda \eta}{\lambda-1} E_{t-1} C_{t}^{*}$ from above. Using log-normality, we can thus write:

$$
\begin{aligned}
E c^{*}+\frac{1}{2} \sigma_{m^{*}}^{2} & \\
= & E c+\frac{n(1-n)^{2}+(1-n) n^{2}}{2} \sigma_{m}^{2}+\frac{n(1-n)^{2}+(1-n) n^{2}}{2} \sigma_{m^{*}}^{2}+\frac{1}{2} \sigma_{c}^{2}-\left(n(1-n)^{2}+(1-n) n^{2}\right) \sigma_{m m^{*}}
\end{aligned}
$$

We have used the fact that $\sigma_{c^{*}}^{2}=\sigma_{m^{*}}^{2}$ because U.S. prices are preset. In the notation used here, $\sigma_{m m^{*}}$ is the covariance between domestic and foreign money shocks. From equation (3.5) in the text:

$$
\sigma_{c}^{2}=n^{2} \sigma_{m}^{2}+(1-n)^{2} \sigma_{m^{*}}^{2}+2 n(1-n) \sigma_{m m^{*}}
$$

Equations (A.3), (A.4) and (A.5) allow us to solve

$$
\begin{aligned}
E c & =\frac{n^{3}(\rho-1)^{2}-n(1-n)(\rho-1)-n}{2 \rho} \sigma_{m}^{2}+\frac{n(1-n)^{2}(\rho-1)^{2}+(1-n)\left((\rho-1)^{2}+n(\rho-1)\right)-(1-n)}{2 \rho} \sigma_{m^{*}}^{2} \\
& +\frac{2 n^{2}(1-n)(\rho-1)^{2}}{2 \rho} \sigma_{m m^{*}}
\end{aligned}
$$

In this model,

$$
E_{t-1}\left(L_{t}\right)=E_{t-1}\left(n \frac{P_{t} C_{t}}{P_{h t}}+(1-n) \frac{P_{t}^{*} C_{t}^{*}}{P_{h t}^{*}}\right)
$$

Using the pricing equations, this reduces simply to 


$$
E_{t-1}\left(L_{t}\right)=\frac{\lambda-1}{\lambda \eta} E_{t-1}\left(C_{t}^{1-\rho}\right) .
$$

So, the welfare criterion can be written as:

$$
\begin{aligned}
E\left(\frac{1}{1-\rho} C^{1-\rho}-\eta L\right) & =\left(\frac{1}{1-\rho}-\frac{\lambda-1}{\lambda}\right) E C^{1-\rho}=\left(\frac{1}{1-\rho}-\frac{\lambda-1}{\lambda}\right)\left(\frac{\lambda-1}{\eta \lambda}\right)^{1-\rho} \rho \exp \left(E c+\frac{(1-\rho)^{2}}{2} \sigma_{c}^{2}\right) \\
& =\frac{(\rho-1)\left[n^{3}(\rho-1)^{2}-n(1-n)(\rho-1)-n\right]+\rho n^{2}(\rho-1)^{2}}{2 \rho} \sigma_{m}^{2} \\
& -\frac{(\rho-1)\left[n(1-n)^{2}(\rho-1)^{2}+(1-n)\left((\rho-1)^{2}+n(\rho-1)\right)-(1-n)\right]+\rho(1-n)^{2}(\rho-1)^{2}}{2 \rho} \sigma_{m^{*}}^{2} \\
& -\frac{(\rho-1)\left[2 n^{2}(1-n)(\rho-1)^{2}\right]+2 \rho(\rho-1)^{2} n(1-n)}{2 \rho} \sigma_{m m^{*}}
\end{aligned}
$$

Under fixed exchange rates, $\sigma_{m}^{2}=\sigma_{m^{*}}^{2}=\sigma_{m m^{*}}$. Under floating rates $\sigma_{m m^{*}}=0$. The welfare

criteria from Table 1 can then be derived from the above expression.

\section{Mixed, Complete Nominal Bond Markets}

$$
\left(P_{M t}^{*}\right)^{n}\left(P_{U t}^{*}\right)^{1-n}=P_{t}^{*}=\frac{\lambda \eta}{\lambda-1} P_{t}^{*} \frac{E_{t-1}\left(C_{t}^{*}\right)}{E_{t-1}\left(C_{t}^{* 1-\rho}\right)} .
$$

This implies

$$
E_{t-1}\left(C_{t}^{* 1-\rho}\right)=\frac{\lambda \eta}{\lambda-1} E_{t-1}\left(C_{t}^{*}\right)
$$

Using log-normality, we get

$$
E c^{*}=\frac{\rho-2}{2} \sigma_{c^{*}}^{2}=\frac{\rho-2}{2} \sigma_{m^{*}}^{2}
$$

Then 


$$
E C^{* 1-\rho}=\left(\frac{\lambda-1}{\eta \lambda}\right)^{1-\rho / \rho} \exp \left(\frac{\rho-1}{2} \sigma_{m^{*}}^{2}\right) .
$$

We also have

$$
\left(P_{M t}\right)^{n}\left(P_{u t}\right)^{1-n}=P_{t}=\frac{\lambda \eta}{\lambda-1} P_{t}\left[\frac{E_{t-1}\left(S_{t}^{1-n} C_{t}\right)}{E_{t-1}\left(C_{t}^{1-\rho}\right)}\right]^{n}\left[\frac{E_{t-1}\left(S_{t}^{-n} C_{t}\right)}{E_{t-1}\left(C_{t}^{1-\rho}\right)}\right]^{1-n} .
$$

We get

$$
E_{t-1}\left(C_{t}^{1-\rho}\right)=\frac{\lambda \eta}{\lambda-1}\left[E_{t-1}\left(S_{t}^{1-n} C_{t}\right)\right]^{n}\left[E_{t-1}\left(S_{t}^{-n} C_{t}\right)\right]^{1-n}
$$

Using log-normality

$$
E c=\frac{\rho-2}{2} \sigma_{c}^{2}-\frac{n(1-n)}{2 \rho} \sigma_{s}^{2} .
$$

It follows that

$$
E C^{1-\rho}=\exp \left(\frac{\rho-1}{2} \sigma_{c}^{2}+\frac{(\rho-1) n(1-n)}{2 \rho} \sigma_{s}^{2}\right) .
$$

From the Mexican and U.S. cash-in-advance constraint, and the risk sharing condition (noting that prices for U.S. households are preset, and that the peso price of Mexican-produced goods for Mexican households is preset):

$$
\begin{aligned}
& \sigma_{c}^{2}=\alpha^{2} \sigma_{m}^{2}+(1-\alpha)^{2} \sigma_{m^{*}}^{2}+2 \alpha(1-\alpha) \sigma_{m m^{*}} \\
& \sigma_{s}^{2}=\frac{\rho^{2} \alpha^{2}}{n^{2}} \sigma_{m}^{2}+\frac{\rho^{2} \alpha^{2}}{n^{2}} \sigma_{m^{*}}^{2}-2 \frac{\rho^{2} \alpha^{2}}{n^{2}} \sigma_{m m^{*}}
\end{aligned}
$$

where 


$$
\alpha \equiv \frac{n}{n+\rho(1-n)}
$$

Substituting in, we get

$$
\begin{aligned}
E C^{1-\rho} & =\left(\frac{\lambda-1}{\eta \lambda}\right)^{1-\rho / \rho} \exp \left(\frac{\rho(\rho-1) \alpha^{2}+(\rho-1) \alpha^{2} \rho^{2}(1-n) / n}{2 \rho} \sigma_{m}^{2}\right. \\
& +\frac{\rho(\rho-1)(1-\alpha)^{2}+(\rho-1) \alpha^{2} \rho^{2}(1-n) / n}{2 \rho} \sigma_{m^{*}}^{2} \\
& \left.+\frac{2 \rho(\rho-1) \alpha(1-\alpha)-2(\rho-1) \alpha^{2} \rho^{2}(1-n) / n}{2 \rho} \sigma_{m m^{*}}\right)
\end{aligned}
$$

In this model, we derive

$$
E_{t-1}\left(L_{t}\right)=\frac{\lambda-1}{\lambda \eta}\left(n E_{t-1}\left(C_{t}^{1-\rho}\right)+(1-n) E_{t-1}\left(C_{t}^{* 1-\rho}\right)\right)
$$

So, the welfare objective function is

$$
\left(\frac{1}{1-\rho}-\frac{n(\lambda-1)}{\lambda}\right) E C^{1-\rho}-\frac{(1-n) \lambda-1}{\lambda} E C^{* 1-\rho} .
$$

Again using the fact that under fixed exchange rates, $\sigma_{m}^{2}=\sigma_{m^{*}}^{2}=\sigma_{m m^{*}}$, and under floating rates $\sigma_{m m^{*}}=0$, the welfare criteria from Table 1 can then be derived from the above expressions.

\section{PTM, Trade Balance}

All consumer prices in both countries are preset in this model. We have

$$
\left(P_{M t}\right)^{n}\left(P_{U t}\right)^{1-n}=P_{t}=\frac{\lambda \eta}{\lambda-1} P_{t}\left[\frac{E_{t-1}\left(C_{t}\right)}{E_{t-1}\left(C_{t}^{1-\rho}\right)}\right]^{n}\left[\frac{E_{t-1}\left(C_{t}\right)}{E_{t-1}\left(C_{t}^{* 1-\rho}\right)}\right]^{1-n} .
$$

These equations imply 


$$
\left[E_{t-1}\left(C_{t}^{1-\rho}\right)\right]^{n}\left[E_{t-1}\left(C_{t}^{* 1-\rho}\right)\right]^{1-n}=\frac{\lambda \eta}{\lambda-1} E_{t-1}\left(C_{t}\right) .
$$

Similarly

$$
\left[E_{t-1}\left(C_{t}^{1-\rho}\right)\right]^{n}\left[E_{t-1}\left(C_{t}^{* 1-\rho}\right)\right]^{\|-n}=\frac{\lambda \eta}{\lambda-1} E_{t-1}\left(C_{t}^{*}\right) .
$$

From these, we obtain

$$
\begin{aligned}
& n\left((1-\rho) E c+\frac{(1-\rho)^{2}}{2} \sigma_{m}^{2}\right)+(1-n)\left((1-\rho) E c^{*}+\frac{(1-\rho)^{2}}{2} \sigma_{m^{*}}^{2}\right)=E c+\frac{1}{2} \sigma_{m}^{2}+\ln \left(\frac{\lambda \eta}{\lambda-1}\right) \\
& n\left((1-\rho) E c+\frac{(1-\rho)^{2}}{2} \sigma_{m}^{2}\right)+(1-n)\left((1-\rho) E c^{*}+\frac{(1-\rho)^{2}}{2} \sigma_{m^{*}}^{2}\right)=E c^{*}+\frac{1}{2} \sigma_{m^{*}}^{2}+\ln \left(\frac{\lambda \eta}{\lambda-1}\right) .
\end{aligned}
$$

Here we have used the fact that in this model $\sigma_{c}^{2}=\sigma_{m}^{2}$ and $\sigma_{c^{*}}^{2}=\sigma_{m^{*}}^{2}$. Solving these we get

$$
E C^{1-\rho}=\left(\frac{\lambda-1}{\eta \lambda}\right)^{1-\rho / \rho} \exp \left(\frac{(\rho-1)(1+(1-n)(\rho-1))}{2} \sigma_{m}^{2}-\frac{(1-n)(\rho-1)^{2}}{2} \sigma_{m^{*}}^{2}\right)
$$

Again in this model

$$
E_{t-1}\left(L_{t}\right)=\frac{\lambda-1}{\lambda \eta} E_{t-1}\left(C_{t}^{1-\rho}\right)
$$

So the welfare expression is given by

$$
E\left(\frac{1}{1-\rho} C^{1-\rho}-\eta L\right)=\left(\frac{1}{1-\rho}-\frac{\lambda-1}{\lambda}\right) E C^{1-\rho}
$$

We can arrive at the welfare criteria for fixed versus floating (reported in Table 1) just as in the previous cases. In particular, we find simply that floating rates are preferred to fixed rates when $\sigma_{m}^{2}<\sigma_{m^{*}}^{2}$ 


\section{PTM, Complete Nominal Bond Markets}

Here we have

$$
\left(P_{M t}\right)^{n}\left(P_{U t}\right)^{1-n}=P_{t}=\frac{\lambda \eta}{\lambda-1} P_{t}\left[\frac{E_{t-1}\left(C_{t}\right)}{E_{t-1}\left(C_{t}^{1-\rho}\right)}\right]^{n}\left[\frac{E_{t-1}\left(C_{t}\right)}{E_{t-1}\left(C_{t}^{1-\rho}\right)}\right]^{1-n}
$$

so

$$
E_{t-1}\left(C_{t}^{1-\rho}\right)=\frac{\lambda \eta}{\lambda-1} E_{t-1}\left(C_{t}\right)
$$

Similarly,

$$
E_{t-1}\left(C_{t}^{* 1-\rho}\right)=\frac{\lambda \eta}{\lambda-1} E_{t-1}\left(C_{t}^{*}\right)
$$

We can solve these to find

$$
E C^{1-\rho}=\left(\frac{\lambda-1}{\eta \lambda}\right)^{1-\rho / \rho} \exp \left(\frac{\rho-1}{2} \sigma_{m}^{2}\right)
$$

and

$$
E C^{* 1-\rho}=\left(\frac{\lambda-1}{\eta \lambda}\right)^{1-\rho / \rho} \exp \left(\frac{\rho-1}{2} \sigma_{m^{*}}^{2}\right)
$$

where we have used the fact that in this model $\sigma_{c}^{2}=\sigma_{m}^{2}$ and $\sigma_{c^{*}}^{2}=\sigma_{m^{*}}^{2}$. Since in this model

$$
E_{t-1}\left(L_{t}\right)=\frac{\lambda-1}{\lambda \eta}\left(n E_{t-1}\left(C_{t}^{1-\rho}\right)+(1-n) E_{t-1}\left(C_{t}^{* 1-\rho}\right)\right),
$$

we have the utility term is: 


$$
\left(\frac{1}{1-\rho}-\frac{n(\lambda-1)}{\lambda}\right) E C^{1-\rho}-\frac{(1-n) \lambda-1}{\lambda} E C^{*_{1}-\rho} .
$$

We arrive at the results in Table 1 as in the previous sections.

\section{PCP}

As in case 4 , we get

$$
\left(P_{M t}\right)^{n}\left(P_{u t}\right)^{1-n}=P_{t}=\frac{\lambda \eta}{\lambda-1} P_{t}\left[\frac{E_{t-1}\left(S_{t}^{1-n} C_{t}\right)}{E_{t-1}\left(C_{t}^{1-\rho}\right)}\right]^{n}\left[\frac{E_{t-1}\left(S_{t}^{-n} C_{t}\right)}{E_{t-1}\left(C_{t}^{1-\rho}\right)}\right]^{1-n}
$$

which implies

$$
E_{t-1}\left(C_{t}^{1-\rho}\right)=\frac{\lambda \eta}{\lambda-1}\left[E_{t-1}\left(S_{t}^{1-n} C_{t}\right)\right]^{n}\left[E_{t-1}\left(S_{t}^{-n} C_{t}\right)\right]^{1-n},
$$

and thus

$$
E C^{1-\rho}=\exp \left(\frac{\rho-1}{2} \sigma_{c}^{2}+\frac{(\rho-1) n(1-n)}{2 \rho} \sigma_{s}^{2}\right) .
$$

Since in this model $S_{t}=M_{t} / M_{t}^{*}$ and $C_{t}=C_{t}^{*}$, we have

$$
\sigma_{c}^{2}=n^{2} \sigma_{m}^{2}+(1-n)^{2} \sigma_{m^{*}}^{2}+2 n(1-n) \sigma_{m m^{*}}
$$

and

$$
\sigma_{s}^{2}=\sigma_{m}^{2}+\sigma_{m^{*}}^{2}-2 \sigma_{m m^{*}} .
$$

Plugging in, we get 


$$
\begin{aligned}
E C^{1-\rho} & =\left(\frac{\lambda-1}{\eta \lambda}\right)^{1-\rho / \rho} \exp \left(\frac{\rho(\rho-1) n^{2}+(\rho-1) n(1-n)}{2 \rho} \sigma_{m}^{2}\right. \\
& +\frac{\rho(\rho-1)(1-n)^{2}+(\rho-1) n(1-n)}{2 \rho} \sigma_{m^{*}}^{2} \\
& \left.+\frac{2 \rho(\rho-1) n(1-n)-2(\rho-1) n(1-n)}{2 \rho} \sigma_{m m^{*}}\right)
\end{aligned}
$$

Also, since $C_{t}=C_{t}^{*}$,

$$
E_{t-1}\left(L_{t}\right)=\frac{\lambda-1}{\lambda \eta} E_{t-1}\left(C_{t}^{1-\rho}\right)
$$

and the welfare criterion reduces to maximizing

$$
E\left(\frac{1}{1-\rho} C^{1-\rho}-\eta L\right)=\left(\frac{1}{1-\rho}-\frac{\lambda-1}{\lambda}\right) E C^{1-\rho} .
$$

Using the expressions above, we arrive at the welfare criteria presented in Table 1. 
Figure 1

Variance Decomposition of Mexican-U.S. Real Exchange Rate Changes

(September 1991 - August 1999)

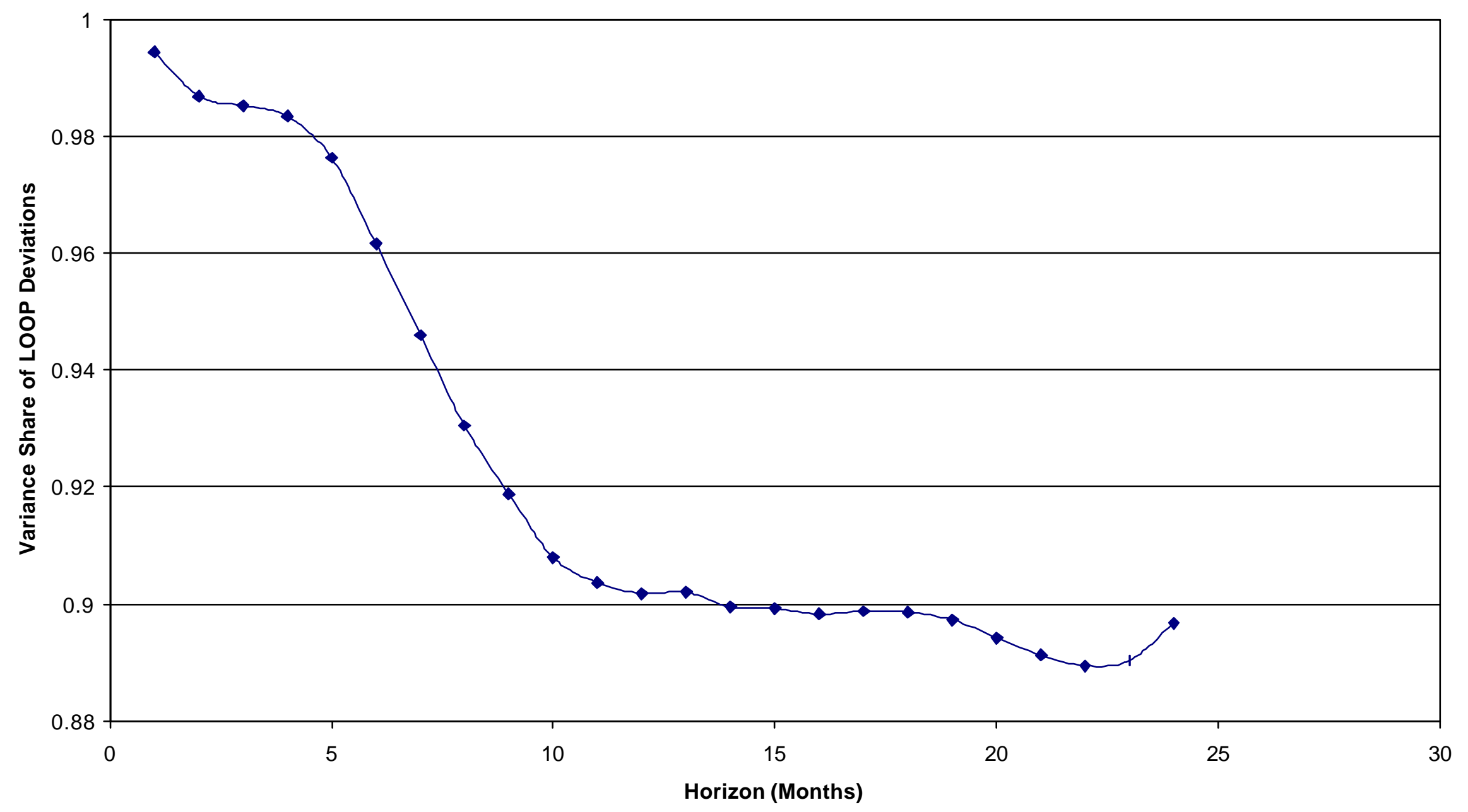


Figure 2

Variance Decomposition Allowing for Marketing Effect

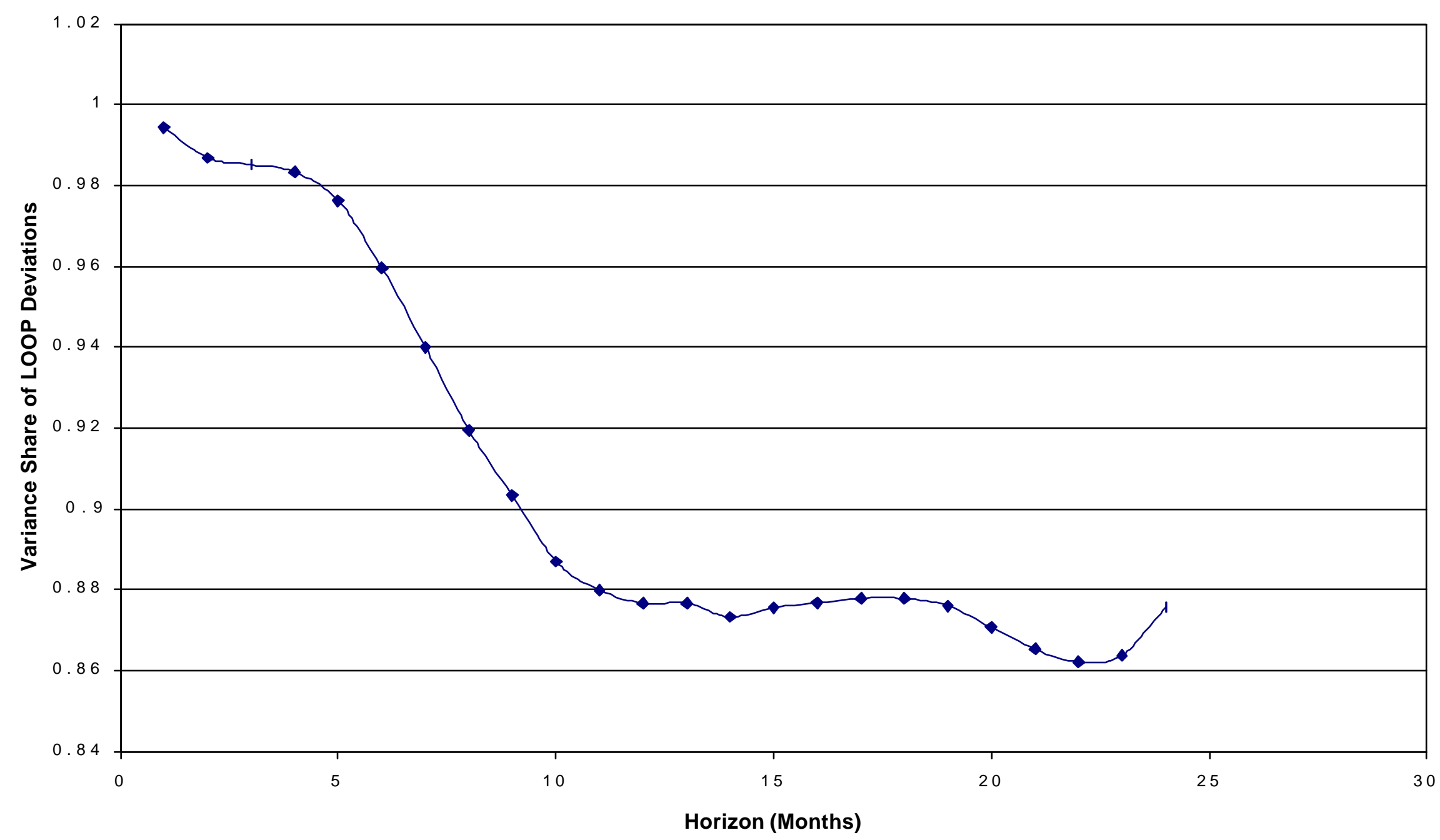


Figure 3

Implied Squared Correlation Coefficients

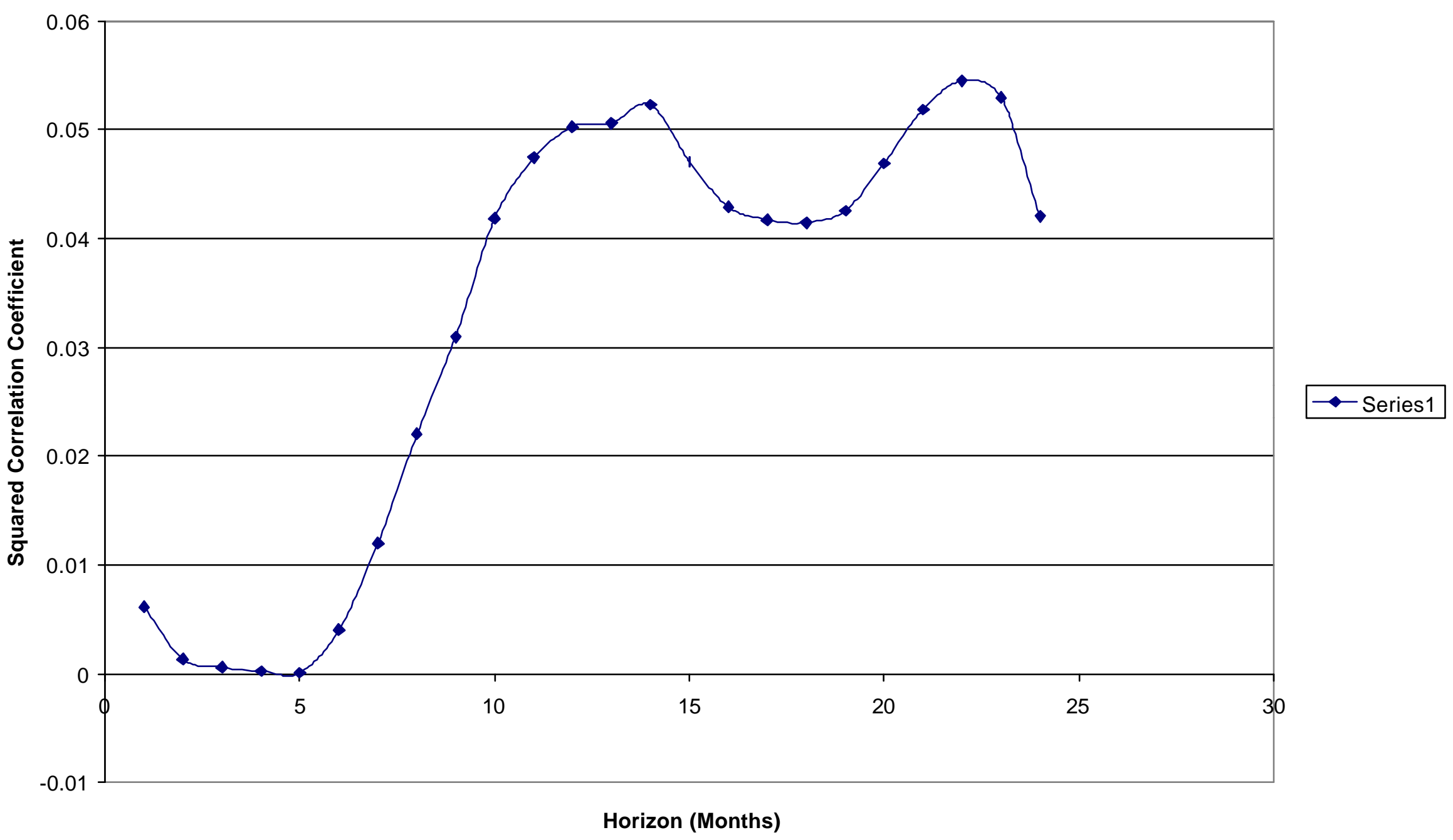


Figure 4

Variance Shares of Tradable Goods

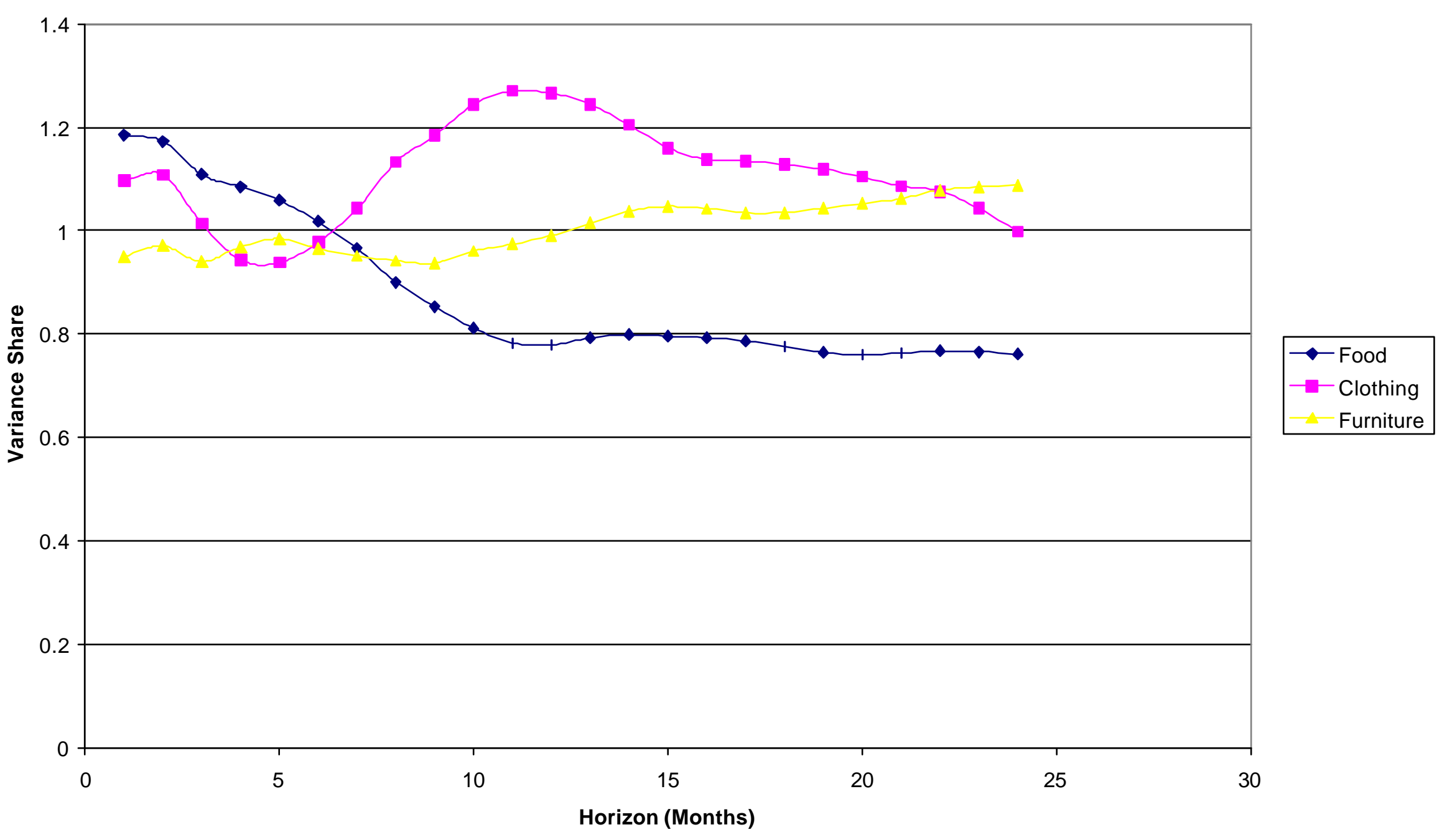


Figure 5

Correlation of Nominal Peso/Dollar Exchange Rate and Relative Traded Goods Prices

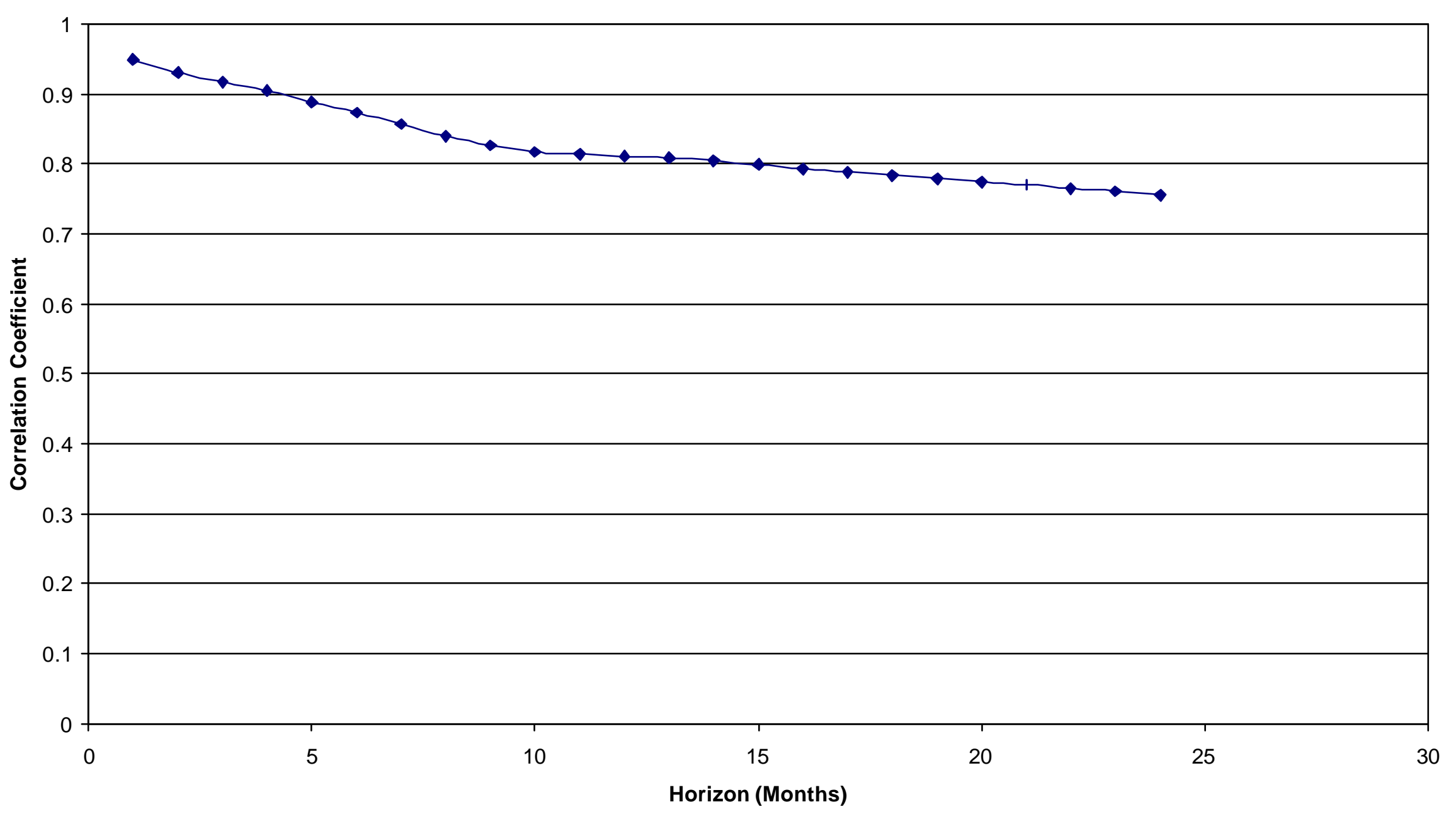

